\title{
Marine reptiles from the Jurassic/Cretaceous transition at the High Andes, Mendoza, Argentina
}

\author{
Marta S. Fernández ${ }^{\mathrm{a}}$, Yanina Herrera ${ }^{\mathrm{a}, *}$, Verónica V. Vennari ${ }^{\mathrm{b}}$, Lisandro Campos $^{\mathrm{a}}$, \\ Marcelo de la Fuente $^{\mathrm{b}}$, Marianella Talevi ${ }^{\mathrm{c}}$, Beatriz Aguirre-Urreta ${ }^{\mathrm{d}}$ \\ a División Paleontología Vertebrados, Museo de La Plata, FCNyM, UNLP, CONICET, Av. 60 y 122, B1900AVW, La Plata, Argentina \\ ${ }^{\mathrm{b}}$ Grupo vinculado al Instituto Argentino de Nivología, Glaciología y Ciencias Ambientales (IANIGLA). CONICET. Museo de Historia Natural de San Rafael, Parque \\ Mariano Moreno s/n, M5602DPH San Rafael, Mendoza, Argentina \\ ${ }^{\mathrm{c}}$ Instituto de Investigación en Paleobiología y Geología (UNRN-CONICET), Av. Roca 1242, R8332EXZ General Roca, Río Negro, Argentina \\ d Instituto de Estudios Andinos "Don Pablo Groeber" (UBA-CONICET), Departamento de Ciencias Geológicas, Facultad de Ciencias Exactas y Naturales, UBA, Intendente \\ Güiraldes 2160 Ciudad Universitaria - Pabellón II, C1428EGA CABA, Argentina
}

\section{A R T I C L E I N F O}

\section{Keywords:}

Ichthyosaurs

Metriorhynchids

Turtles

Biostratigraphy

Vaca Muerta Formation

Tithonian-Berriasian

\begin{abstract}
A B S T R A C T
Upper Jurassic and Lower Cretaceous deposits of the Vaca Muerta Formation (Neuquén Basin, central-west Argentina) have yielded abundant marine reptile remains. Most of them correspond to faunal assemblages recovered from outcrops in the Neuquén Province (Argentina). Herein we report two new marine reptile-bearing localities documenting the Tithonian-Berriasian transition at the High Andes (Mendoza Province, Argentina). Marine reptiles have been mapped and/or collected in connection with an accurate ammonoid-based biostratigraphic control. All the skeletons have been found preserved in, or associated with, calcareous nodules. At both localities they are frequent in beds assigned to the upper Tithonian Corongoceras alternans ammonite Zone (Microcanthum to "Durangites" Standard Zones), and are rare to common in beds assigned to the upper Tithonian-lower Berriasian Substeueroceras koeneni Zone ("Durangites" to Jacobi Standard Zones). Newly discovered assemblages depict a similar pattern characterized by the lack of plesiosaurs (plesiosauroids and pliosaurids), and by the abundance of mesoconsumers represented by ophthalmosaurids and metriorhynchine metriorhynchids. Macropredator geosaurines, apex metriorhynchids predators, and thalassochelydian turtles are rare components of these assemblages.
\end{abstract}

\section{Introduction}

A critical period in the evolutionary history of marine tetrapods is the Jurassic/Cretaceous transition. Whether this interval was characterized by faunal turnovers and, if so, which climatic or biotic factors could have driven such changes are still controversial (e.g. Benson and Druckenmiller, 2014; Fischer et al., 2012; Tennant et al., 2016, 2017; Zverkov et al., 2018). Marine reptile-bearing localities documenting this transition are still scarce and/or poorly studied with a remarkable exception concerning the northern high latitude Slottsmøya Member Largestätte (SML) of the Agardhfjellet Formation (Spitsbergen, Svalbard archipelago, Norway) (Delsett et al., 2016, 2017; Druckenmiller et al., 2012; Hurum et al., 2012; Kear et al., 2015; Knutsen et al., 2012a, b, c; Roberts et al., 2014). From southern latitudes, rich Tithonian marine reptile faunas from the Vaca Muerta Formation (Neuquén Basin, Argentina) have been extensively reported (e.g. Gasparini and Fernández, 2005, 2011; Gasparini et al., 2015) although only one contribution focused on the Jurassic/Cretaceous transition (Spalletti et al., 1999). Those authors described an important Tithonian-Berriasian marine reptile bearing locality at the Yesera del Tromen-Pampa Tril (central Neuquén Basin, Neuquén Province, Argentina). Despite the extensive exposures of the Vaca Muerta Formation in Mendoza, and the fossiliferous richness depicted by the localities of the Malargüe sector (southern Mendoza), marine reptile records are so far strongly biased towards those occurring at the southern and central sectors of the basin (i.e. the Neuquén Embayment; Bracaccini, 1970). Thus, although some of the first marine reptiles from South America were collected in southern Mendoza (Bodenbender, 1892; Dames, 1893), the fossiliferous

\footnotetext{
* Corresponding author. División Paleontología Vertebrados, Museo de La Plata, FCNyM, UNLP, Av. 60 y 122, B1900AVW La Plata, Argentina.

E-mail addresses: martafer@fcnym.unlp.edu.ar (M.S. Fernández), yaninah@fcnym.unlp.edu.ar (Y. Herrera), vvennari@mendoza-conicet.gob.ar (V.V. Vennari), lcampos@fcnym.unlp.edu.ar (L. Campos), mdelafuente@mendoza-conicet.gob.ar (M. de la Fuente), mtalevi@unrn.edu.ar (M. Talevi), aguirre@gl.fcen.uba.ar (B. Aguirre-Urreta).
} 


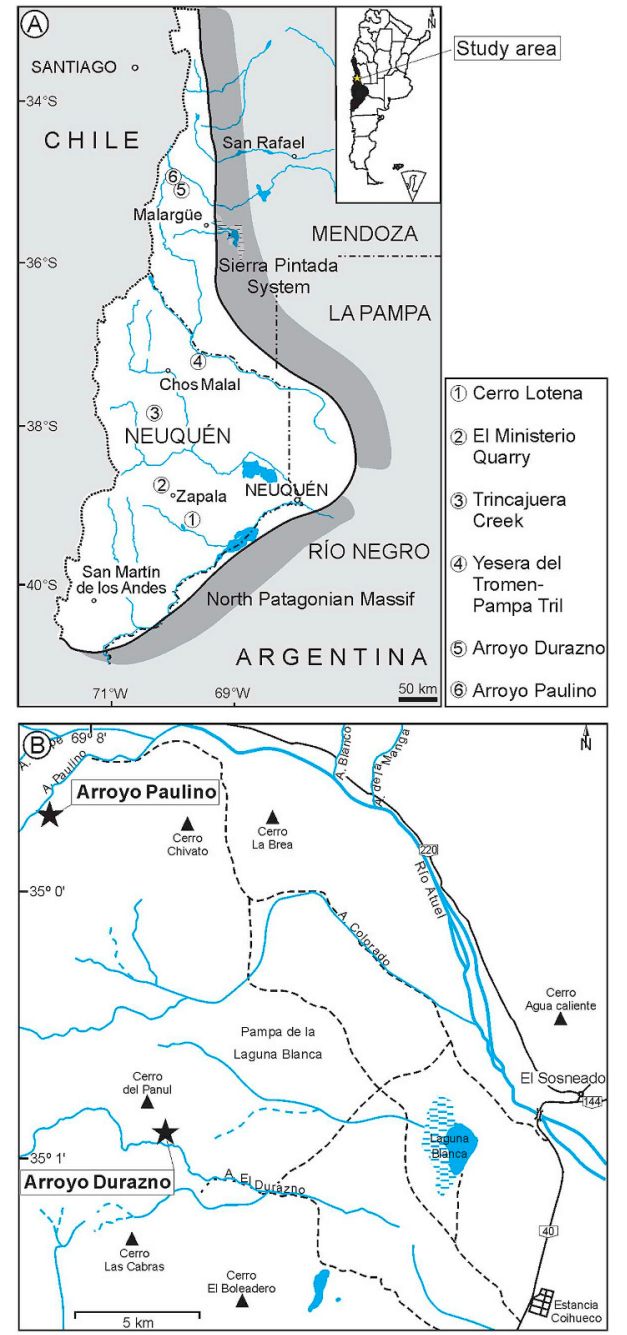

Fig. 1. A, Neuquén Basin location showing the marine reptile-bearing localities at Mendoza (study area), and Neuquén provinces. B, Detailed map of the study area depicting Arroyo Durazno and Arroyo Paulino localities.

localities from this sector of the basin have been traditionally subsampled for marine vertebrates. In the middle of the 20th Century, Rusconi (1938, 1948a, b, 1967) described and nominated ichthyosaurs and a "plesiosaur" from southern Mendoza but most of these names are currently considered as nomina dubia and/or reassigned to other lineages. Since then, marine reptiles from Mendoza have been sporadically studied and/or reported (de la Fuente et al., 2016; Fernández, 2003; Gasparini, 1973; Goñi, 1987; Vennari et al., 2007; Vignaud and Gasparini, 1996).

Fieldwork conducted over the last nine years in southern Mendoza resulted in the identification of two new Tithonian-Berriasian fossiliferous localities: Arroyo Durazno and Arroyo Paulino (Fig. 1). As the first reptilian findings comprised well three-dimensionally preserved specimens, during 2016 and 2017 three additional fieldworks were conducted in both localities but focused on marine reptile remains. Those remains were documented in connection with an accurate ammonoid-based biostratigraphic control (Fig. 2). In this contribution we report and describe the newly discovered assemblages, and compare them with other Tithonian-Berriasian faunas already known from the Neuquén Embayment and other latitudes.

\subsection{Historical background of marine reptile findings in Mendoza Province}

One of the first Jurassic marine reptile findings from South America was found in southern Mendoza. In 1892, during a geological survey at the Andes, the geologist Guillermo Bodenbender collected five ichthyosaur vertebrae from Tithonian levels at Arroyo de la Cieneguita. Previously, one rib fragment and one vertebra of an ichthyosaur were described as the new species Ichthyosaurus leucopetraeus from Copiapó, Chile (Burmeister and Giebel, 1861), but this name is a nomen dubium (McGowan and Motani, 2003). The vertebrae collected by Bodenbender were described by Dames (1893) as the new species Ichthyosaurus bodenbenderi. The vertebral centra were relatively small (height range $=75-80 \mathrm{~mm}$ ) and, as they depict no diagnostic features, this name has also been considered as a nomen dubium (Fernández, 2007; McGowan and Motani, 2003). In 1895, the German naturalist Rodulfo Amando Philippi (1895) reported dorsal and caudal vertebrae, ribs, one humerus, and a partial pelvic bone of an ichthyosaur found at the Cajón del Durazno (south of Mendoza). Based on those materials he erected the new species Ichthyosaurus immanis. Unfortunately, that contribution included no figures and was focused on the description of the vertebrae. Furthermore, the bones that would have some diagnostic value (i.e. humerus and "pelvic bone") were only briefly mentioned. In recent years the phylogenetic signals of the humerus and pelvic bones among ophthalmosaurid ichthyosaurs have been highlighted (e.g. Delsett et al., 2017; Fischer et al., 2014; Maxwell, 2010) but unfortunately, as the materials reported by Philippi could not be found for re-study, 'I. immanis' must still be considered as nomen dubium. Based on these historical findings, Carlos Rusconi conducted several fieldtrips in southern Mendoza during the $40^{\prime}$ and $50^{\prime}$ of the 20th Century, and recovered new materials. He described the newly discovered reptiles as well as other specimens found by local people. Unfortunately, all these findings are not properly contextualized, geologically or even geographically, hampering their interpretations. In his first contribution on ichthyosaurs he nominated the new species Myobradypterygius mollensis Rusconi, 1938, based on 46 dorsal and caudal vertebrae and some ribs, and also mentioned a second specimen comprising a mandibular fragment with some teeth. The provenance of these specimens was indicated as $4 \mathrm{~km}$ east of the "Puente del Ictiosaurio" (Ichthyosaurus Bridge), Late Jurassic in age (Rusconi, 1938: p. 4). In 1940 he described another specimen consisting of 40 cervical, dorsal and lumbar vertebrae, a pectoral girdle and an incomplete forelimb. Based on the comparison with 'Myobradypterygius' hauthali Huene, 1927, from the Barremian of Santa Cruz Province (Argentina), he described and named the Mendoza ichthyosaur as the new species Myobradypterygius mendozanus Rusconi, 1940. The provenance of its holotype is also unclear: Bardas Blancas, $200 \mathrm{~m}$ north of the "Puente del Río Grande", Malargüe Department, Jurassic and probably Liassic in age (Rusconi, 1940: p. 2). In a later contribution, Rusconi (1942) considered that the differences between the ichthyosaur from Mendoza and 'Myobradypterygius' hauthali were remarkable and proposed the new genus Ancanamunia, for the reception of 'M.' mollensis and 'M.' mendozana; he designated the latter as the holotype. However, based mainly on the forefin morphology, Fernández (1997) synonymized Ancanamunia Rusconi, 1942 and Ophthalmosaurus Seeley, 1874; and McGowan and Motani (2003) synonymized Ancanamunia mendozana and Baptanodon natans. In a review of the ichthyosaurs from Mendoza, Rusconi (1948a) nominated two other "ichthyosaur" species: Ichthyosaurus saladensis (from Bajada de las Vacas) and Ichthyosaurus inexpectatus (from Cajón del Río Grande). However, only the first name refers to an ichthyosaur, since the second reptile (I. inexpectatus) corresponds to a metriorhynchid, likely Dakosaurus (Vignaud and Gasparini, 1996). Ichthyosaurus saladensis was based on mandibular fragments with teeth and some elements of the pectoral girdle. As the material referred to I. saladensis is very incomplete and lacks diagnostic features, this name has been considered as nomen dubium (Fernández, 2007; McGowan and Motani, 2003). Rusconi (1948b) recovered remains of a "plesiosaur" in the same locality as 'Ichthyosaurus inexpectatus'. He described these remains as the new genus and species Purranisaurus potens. Gasparini (1973) noticed that the holotype (and only known specimen) has been 


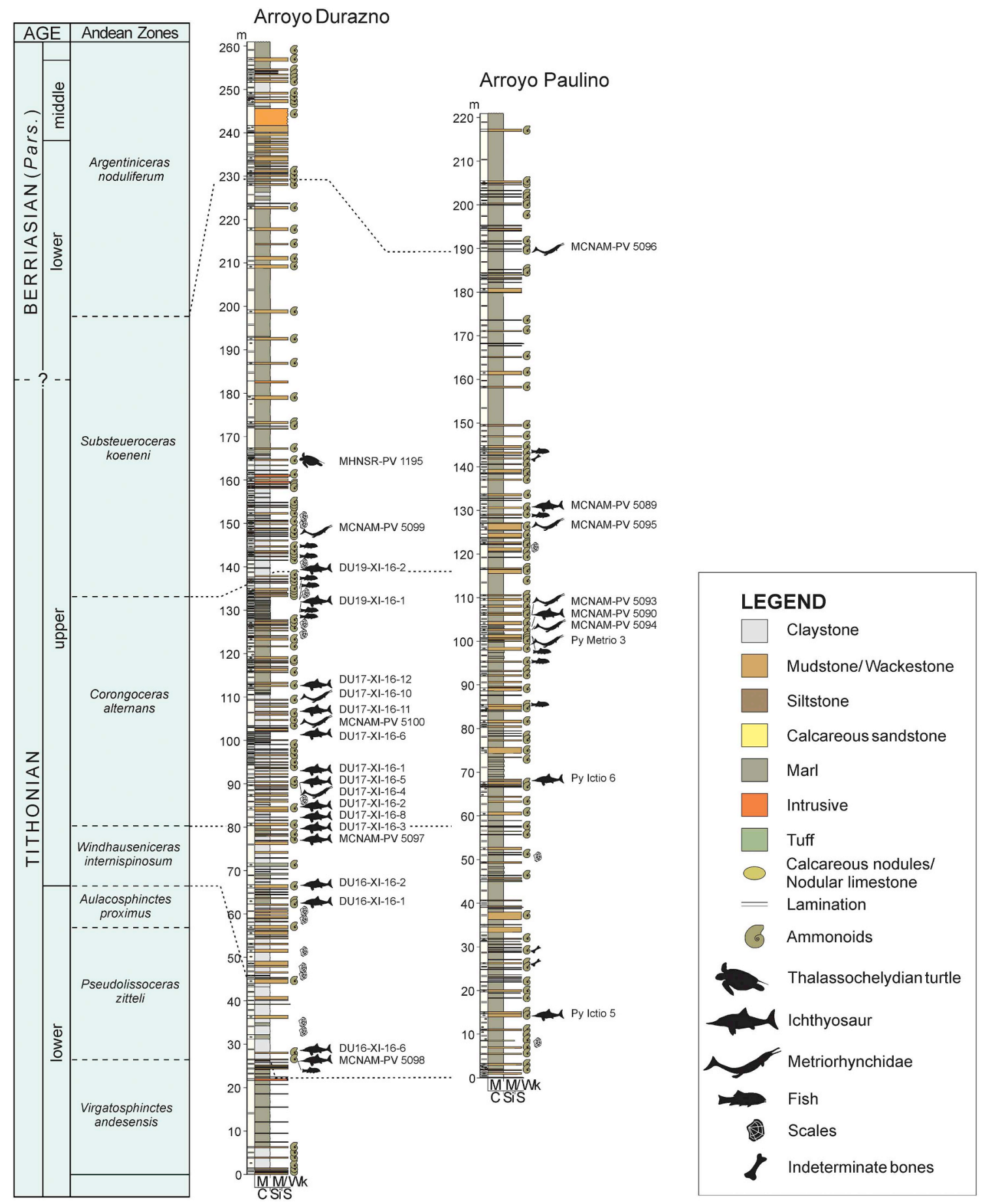

Fig. 2. Detailed stratigraphic sections of Arroyo Durazno and Arroyo Paulino localities showing the position of marine reptiles and associated ammonites in the lower Tithonian to lower lower-middle Berriasian (Arroyo Durazno) and in the upper Tithonian to lower Berriasian (Arroyo Paulino).

misidentified and she referred it to Metriorhynchidae indet., and in 1985 she proposed Purranisaurus as a synonym of Metriorhynchus von Meyer (1830) (Gasparini, 1985). However, Herrera et al. (2015) revalidated Purranisaurus potens as a valid genus and species of metriorhynchid and, based on an associated ammonite shell, they proposed a late Tithonian-early Berriasian age for this taxon. This is quite significant as it is, up to date, the only material described by Rusconi with a constrained age. Other marine crocodylomorphs from Mendoza are two dorsal vertebrae from Portezuelo Ancho described by Huene (1927) as Steneosaurus gerthi and currently considered nomen dubium (Pol and Gasparini, 2007), and two natural endocasts of the skull cavities referred to Cricosaurus araucanenis (MLP 76-XI-19-1 and MLP 84-V-1-1) found in Tithonian levels of Sierra de Reyes (e.g. Herrera, 2015). The holotype of the metriorhynchid Dakosaurus andiniensis comes also from Tithonian levels of the Vaca Muerta Formation in southern Mendoza (Vignaud and Gasparini, 1996). Although incomplete, a significant ichthyosaur remain from southern Mendoza is a partial forefin from the Aalenian-Bajocian boundary of the Los Molles Formation cropping out at Quebrada Remoredo (western slope of Sierra de Reyes). This specimen represents the oldest record of an ophthalmosaurid ichthyosaur worldwide (Fernández, 2003). 


\section{Geological setting and fossil localities}

The Neuquén Basin is a retro-arc basin extending between $33^{\circ}$ and $39^{\circ}$ South Latitude, across western-central Argentina and central Chile (Legarreta and Uliana, 1991) (Fig. 1A). The basin was limited by cratonic areas to the east and by an active discontinuous volcanic arc to the west which was mostly developed over the Chilean territory and allowed the communication with the Pacific Ocean (Legarreta and Uliana, 1999). The sedimentary column records nearly uninterruptedly from the Late Triassic to the Cenozoic, including those Jurassic/Cretaceous transitional beds here reported. Sedimentation within the basin was mainly controlled by eustatic oscillations which would have been more relevant than local tectonic events according to some authors (Legarreta and Gulisano, 1989). By contrast, other researchers sustain that the evolution of the Neuquén Basin was more related to the development of the Andes and the geometry of the subducted slab in that sector (Ramos and Folguera, 2005).

Tithonian-Berriasian successions bearing the herpetofauna herein studied are included in the Vaca Muerta Formation (Weaver, 1931), one of the most geographically extended units of the Mendoza Group (Groeber, 1946). Deposition of this unit began with a sudden marine flooding during the early Tithonian and extended up to the early Valanginian. The Vaca Muerta Formation is highly fossiliferous and characterized by the alternation of dark bituminous clays, marls and massive and nodular limestones beds deposited over a carbonate ramp setting that evolved to a carbonate platform during the Berriasian (Legarreta and Uliana, 1991).

The marine reptiles here presented were recorded in two sections of the Vaca Muerta Formation. The outcrops, $14 \mathrm{~km}$ apart, are exposed over the eastern flank of a NW-SE syncline, in southern Mendoza:

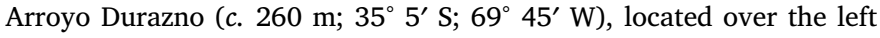
margin of the El Durazno Creek, to the south, and Arroyo Paulino (c. $220 \mathrm{~m} ; 34^{\circ} 58^{\prime} \mathrm{S} ; 69^{\circ} 49^{\prime} \mathrm{W}$ ), cropping out on the right margin of the Paulino Creek, to the north. Both localities are accessed through the National Route 40 heading Malargüe City and then following country roads that fork to the west (Fig. 1B). Main geological features of the area were studied by Ugarte (1955), Dessanti (1978) and Nullo et al. (2005).

Marine reptiles were sampled with an accurate ammonoid-based biostratigraphic control. Indeed, over the basis of bed-by-bed ammonoid sampling, an early Tithonian to early-middle Berriasian age span was determined for the succession studied at Arroyo Durazno (Virgatosphinctes andesensis to the base of Argentiniceras noduliferum Andean Assemblage Zones; Darwini/Semiforme to Occitanica Standard Zones). While a late Tithonian to early Berriasian age span was proposed for the interval analyzed at Arroyo Paulino (Windhauseniceras internispinosum to the base of $A$. noduliferum Andean Assemblage Zones; Microcanthum to Occitanica Standard Zones) (Fig. 2).

\section{Material and methods}

Marine reptiles were sampled from both sections of the Vaca Muerta Formation over three field seasons: Arroyo Durazno (November 2016) and Arroyo Paulino (February and April 2017). Best preserved and/or well exposed parts of the skeletons were collected as voucher specimens (Figs. 3-8). Most of the voucher specimens are housed at MCNAM, except for one previously found that is housed at MHNSR. Data of the marine reptiles from both localities, including taxonomical identification, are summarized in Tables 1-4. Most of the specimens that were mapped during fieldwork but that were not collected are here figured and included as Supplementary data (Figs. S1-S4). The acronym DU refers to Arroyo Durazno while Py refers to Arroyo Paulino and, together with a code number, are here used to identified those specimens still located in the field. For descriptive purposes, the relative abundance of each lineage at the two sampled sections and other localities previously reported, was recorded as rare (1-2 specimens), common (3-10 specimens), and abundant ( $>10$ specimens) (McMullen et al., 2014).

\subsection{Institutional abbreviations}

BSPG, Bayerische Staatssammlung für Paläontologie und Geologie, Munich, Germany; MACN, Museo Argentino de Ciencias Naturales Bernardino Rivadavia, CABA, Argentina; MCNAM, Museo de Ciencias Naturales y Antropológicas J.C. Moyano, Mendoza, Argentina; MHNSR, Museo de Historia Natural de San Rafael, San Rafael, Argentina; MLP, Museo de La Plata, La Plata, Argentina; MOZ, Museo Provincial de Ciencias Naturales "Prof. Dr. Juan A. Olsacher", Zapala, Argentina; SMNS, Staatliches Museum für Naturkunde, Stuttgart, Germany.

\subsection{Anatomical abbreviations}

aac, atlas-axis complex; ana, atlantic neural arch; ar, articular region; asin, antorbital sinus; axna, neural arch of the axis; bs, basisphenoid; bo, basioccipital; ca, carina; cc, cervical centrum; cen, vertebral centrum; cnp, nasal cavity proper; cqf, cranioquadrate foramen; dia, diapophysis; dp, dorsal process; dpc, deltopectoral crest; fe, femur; $\mathrm{fm}$, foramen magnum; fr, frontal; gd, duct of the gland; gl, exocrine nasal gland; icf, internal carotid foramen; il, ilium; isp, ischiopubis; $j$, jugal; mc, medullary canal; mx, maxilla; mx-na, maxilla-nasal suture; na, nasal; na-fr, nasal-frontal suture; na-na, nasal-nasal suture; ne, neural spine; olf, olfactory region of the nasal cavity; ot, otoccipital; pa, parietal; pal, palatine; par, parapophysis; paxef, preaxial accesory element facet; pfr, prefrontal; pfr-fr, prefrontal-frontal suture; pfr-la, prefrontal-lacrimal suture; po, postorbital; poz, postzygapophysis; prz, prezygapophysis; pt, pterygoid; rf, radial facet; sc, scapula; scm, sulcus cartilaginis meckelii; so, supraoccipital; sp, synapophysis; sq, squamosal; s.r, sacral rib; stf, supratemporal fenestra; to/st, temporo-orbital/stapedial vein; tp, transverse process; uf, ulnar facet; vo, vomer; IX-XI, cranial nerves foramen.

\section{Results}

At Arroyo Durazno, ichthyosaur records are abundant, metriorhynchids are common, turtles are rare, and no plesiosaurs have been found. Fourteen ichthyosaurs, four metriorhynchids and one thalassochelydian turtle were identified in situ, making up a total of 19 specimens (Table 1). Additionally, five ichthyosaurs and five metriorhynchids were found ex situ (Table 2). At Arroyo Paulino, the records of ichthyosaurs and metriorhynchids are common, whereas no turtles or plesiosaurs have been found. Four ichthyosaurs and five metriorhynchids were identified in situ (Table 3), and one ichthyosaur and one metriorhynchid were found ex situ (Table 4). At both localities most of the reptiles have been found in beds assigned to the Corongoceras alternans ammonite Zone (Fig. 2, Tables 1 and 3). The 40 marine reptiles found were mapped and 15 partial skeletons were partially excavated and housed in museums of Mendoza (MCNAM and MHNSR) as voucher specimens.

\subsection{Arroyo Durazno}

\subsubsection{Ichthyosaurs}

Ichthyosauria Blainville, 1835

Ophthalmosauridae Baur, 1887

Platypterygiinae Arkhangelsky, 2001 (sensu Fischer et al., 2012)

Platypterygiinae indet.

Fig. 3; Table 1 
Table 1

In situ specimens from Arroyo Durazno.

\begin{tabular}{|c|c|c|c|c|}
\hline $\begin{array}{l}\text { Collection or field } \\
\text { number }\end{array}$ & Andean ammonite Zone & Taxon & Preserved elements & Figure reference \\
\hline MHNSR-PV 1195 & Substeueroceras koeneni & Neusticemys neuquina & $\begin{array}{l}\text { Incompletely preserved skull, cervical vertebrae, partial scapular and } \\
\text { pelvic girdles, left and right humeri, left femur and tibia, plastral, costal } \\
\text { and peripheral bones }\end{array}$ & Fig. 5O-Q \\
\hline MCNAM-PV 5099 & Substeueroceras koeneni & Cricosaurus sp. & Incompletely preserved skull, teeth, cervical vertebrae, coracoid & Fig. 5A-G \\
\hline DU 19-XI-16-2 & Substeueroceras koeneni & Ichthyosauria indet. & Partially preserved mandible & Not figured \\
\hline DU 19-XI-16-1 & Corongoceras alternans & Ichthyosauria indet. & Partially preserved mandible, vertebrae, ribs & Fig. S1K \\
\hline DU 17-XI-16-12 & Corongoceras alternans & Ichthyosauria indet. & Vertebrae, ribs & Fig. S1H \\
\hline DU 17-XI-16-10 & Corongoceras alternans & Metriorhynchidae indet. & Partially preserved cranium & Fig. S2E-F \\
\hline DU 17-XI-16-11 & Corongoceras alternans & Ichthyosauria indet. & Dorsal vertebrae & Fig. S1F \\
\hline MCNAM-PV 5100 & Corongoceras alternans & Geosaurini indet. & Partially preserved dorsal vertebrae and right humerus & Fig. $5 \mathrm{H}-\mathrm{K}$ \\
\hline DU 17-XI-16-1 & Corongoceras alternans & Ichthyosauria indet. & Vertebrae (10), ribs & Fig. S1A \\
\hline DU 17-XI-16-4 & Corongoceras alternans & Metriorhynchidae indet. & Fragmentary skull, teeth, pectoral girdle elements & Fig. S2A \\
\hline DU 17-XI-16-5 & Corongoceras alternans & Ichthyosauria indet. & Vertebrae & Fig. S1E \\
\hline DU 17-XI-16-2 & Corongoceras alternans & Ichthyosauria indet. & Posterior dorsal vertebrae, ribs & Fig. S1B \\
\hline DU 17-XI-16-8 & Corongoceras alternans & Ichthyosauria indet. & Vertebrae & Fig. S1G \\
\hline DU 17-XI-16-3 & Corongoceras alternans & Ichthyosauria indet. & Vertebrae & Fig. S1D \\
\hline MCNAM-PV 5097 & W. internispinosum & Platypterygiinae indet. & $\begin{array}{l}\text { Cervical vertebrae (including the atlas-axis complex), neural arches, } \\
\text { fragmentary ribs, humerus, teeth }\end{array}$ & Fig. 3 \\
\hline DU 16-XI-16-2 & $\begin{array}{l}\text { between } A \text {. proximus and } W \text {. } \\
\text { internispinosum }\end{array}$ & Ichthyosauria indet. & - & Not figured \\
\hline DU 16-XI-16-1 & Aulacosphinctes proximus & Ichthyosauria indet. & Dorsal vertebrae & Not figured \\
\hline DU 16-XI-16-6 & Pseudolissoceras zitteli & Ichthyosauria indet. & Vertebrae, ribs & Not figured \\
\hline MCNAM-PV 5098 & Pseudolissoceras zitteli & Ophthalmosauridae indet. & Cranial and postcranial bones including the left humerus & Fig. 4A-C \\
\hline
\end{tabular}

Table 2

Ex situ specimens from Arroyo Durazno.

\begin{tabular}{|c|c|c|c|}
\hline Collection or field number & Taxon & Preserved elements & Figure reference \\
\hline MCNAM-PV 5101 & Metriorhynchidae indet. & Incompletely preserved natural cast of the preorbital region & Fig. 5L-M \\
\hline MCNAM-PV 5102 & Ophthalmosauridae indet. & Incompletely preserved left humerus & Fig. 4D \\
\hline MCNAM-PV 5103 & Metriorhynchidae indet. & Incompletely preserved and damage snout and mandible with teeth & Fig. $5 \mathrm{~N}$ \\
\hline DU 16-XI-16-4 & Metriorhynchidae indet. & Dorsal vertebrae (9), isquium, ilium & Fig. S2D \\
\hline DU 17-XI-16-6 & Ichthyosauria indet. & Partially preserved skull, tooth & Not figured \\
\hline DU 17-XI-16-7 & Metriorhynchidae indet. & Vertebrae & Fig. S2B \\
\hline DU 17-XI-16-13 & Metriorhynchidae indet. & Partially preserved cranium & Fig. S2C \\
\hline DU 18-XI-16-6 & Ichthyosauria indet. & Partially preserved snout with teeth & Fig. S1C \\
\hline DU 18-XI-16-7 & Ichthyosauria indet. & Dorsal vertebra & Fig. S1J \\
\hline DU 19-XI-16-3 & Ichthyosauria indet. & Partially preserved snout & Fig. S1I \\
\hline
\end{tabular}

Material. MCNAM-PV 5097. Skull and postcranium of a mediumsized ichthyosaur preserved within a calcareous nodule, broken by recent weathering. The following bones could be excavated: part of the atlas-axis complex, two cervical centra, disarticulated neural arches and fragmentary ribs, the right humerus and teeth.
Description. Part of the concretion bearing the atlas-axis complex and two anterior vertebrae has been naturally detached from the main block by recent weathering. The lateral surfaces of the vertebrae have been partially eroded; thus, the location of the diapophyses and parapophyses cannot be confidently assessed. The atlas-axis complex bears a
(A)

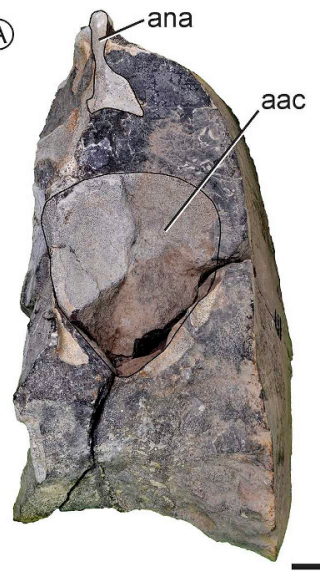

(B)

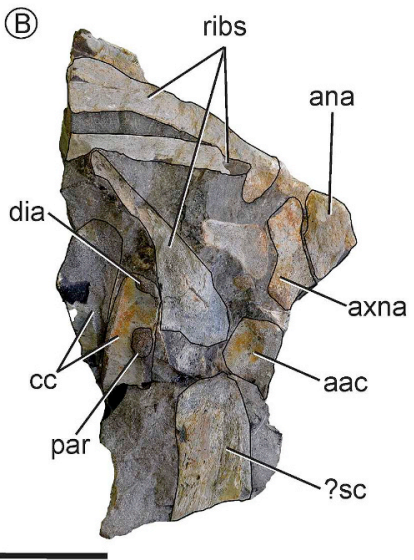

(C)

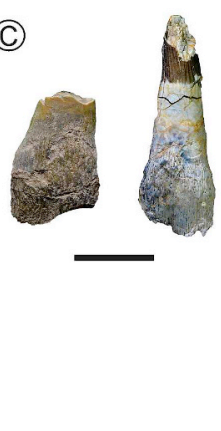

(D)

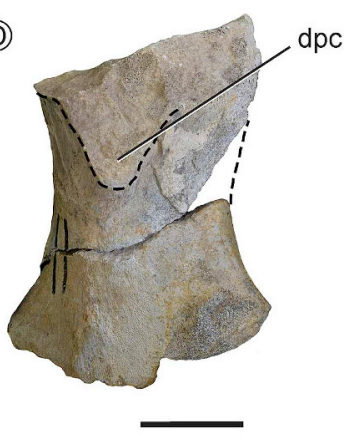

Fig. 3. Platypterygiinae indet. (MCNAM-PV 5097) from Arroyo Durazno. A, Atlas-axis complex and neural arches in anterior view; B, atlas-axis complex, cervical vertebra, neural arches and fragmentary ribs in lateral view; C, isolated teeth in lateral view; D, right humerus in ventral view. Scale bars $=6.5 \mathrm{~cm}(\mathrm{~A}-\mathrm{B}), 1 \mathrm{~cm}(\mathrm{C})$, $3 \mathrm{~cm}(\mathrm{D})$. 
well-developed ventral keel; in anterior view, it is roughly heart-shaped with a maximum width of $65 \mathrm{~mm}$ (Fig. 3A). In lateral view the unfused neural spines of the atlas-axis complex are exposed, as well as the lateral surfaces of the third and fourth cervical centra (Fig. 3B). The 3rd cervical vertebra is the best preserved and it is $24.3 \mathrm{~mm}$ long. The right humerus is mainly exposed in proximal and ventral view (Fig. 3D). In proximal view the locations of the deltopectoral crest and the dorsal process can be confidentially assessed depicting, as in Ophthalmosaurus and Platypterygius (Maxwell, 2010), a strong humeral "torsion" (angle described by the superposition of the long axes of the proximal and distal ends) of approximately $81^{\circ}$. The deltopectoral crest is also welldeveloped and its distal extension does not surpass the proximal half of the humeral shaft. The three fragmentary teeth collected lack their most apical crown region; however, some important features can be observed. The roots are subquadrangular in cross section, the cement is irregularly pitted and has no ridges, and the crowns are conspicuously striated, almost parallel (Fig. 3C). The most complete tooth is $37 \mathrm{~mm}$ long.

Remarks. This specimen is identified as an Ophthalmosauridae, as defined by Motani (1999), based on the plate-like dorsal process and as a Platypterygiinae sensu Fischer et al., 2012 based on the tooth morphology, which is characterized by subquadrangular roots in cross section combined with unridged roots and conspicuous enamel ornamentation.

Ophthalmosauridae indet.

Fig. 4A-C; Table 1

Material. MCNAM-PV 5098. Cranial and postcranial bones of a single specimen included in a calcareous nodule. The left humerus was complete and could be removed from the main block of the nodule. The rest of the skeleton has not been exhumed.
Description. The humerus is stout and robust with a maximum length of $160 \mathrm{~mm}$, and a proximal width/distal width ratio of 0.74 . The head of the humerus is slightly convex, roughly rectangular in proximal view, and its surface is heavily pitted suggesting the persistence of an extensive cartilaginous cap covering this area. The stout deltopectoral crest is anteriorly located, and distally reaches the midpoint of the humeral shaft (Fig. 4A). At this point the humerus has a strong anteroposterior constriction. The humeral "torsion", as in MCNAM-PV 5097 , is also conspicuous, reaching nearly $85^{\circ}$. In dorsal view, the dorsal process reaches approximately the distal half of the bone (Fig. 4B). Distally, the humerus bears three well-developed articular facets, being the ulnar facet strongly posterodistally deflected. In distal view, the ulnar facet is oval, separated from the radial facet by a protruding, dorsoventrally oriented ridge (Fig. 4C).

Remarks. The humerus of MCNAM-PV 5098 strongly resembles that of 'Ancanamunia' mendozana (Rusconi, 1942) (Fig. 4E). The relative expansion of the proximal and distal ends, the degree of humeral torsion, the constriction of the humeral shaft, the curvature of the anterior edge of the shaft, as well as the relative development and location of the deltopectoral crest and the dorsal trochanter of MCNAM-PV 5097 and 5098, are consistent with the morphology of the humerus of 'A.' mendozana. Unlike Caypullisaurus bonapartei (Fig. 4F), the proximal end is anteroposteriorly more expanded, and the shaft constriction is pronounced defining strongly concave anterior and posterior edges. The humerus of MCNAM-PV 5098 also differs from that of Arthropterygius sp. (Fig. 4G) recovered from the Vaca Muerta Formation (Fernández and Maxwell, 2012) in the location and relative development of the deltopectoral crest and dorsal trochanter, and the constriction at the shaft midpoint.

Ophthalmosauridae indet.

Fig. 4D; Table 2
(A)

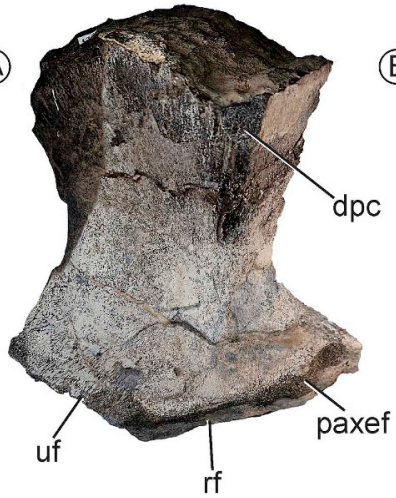

(E)

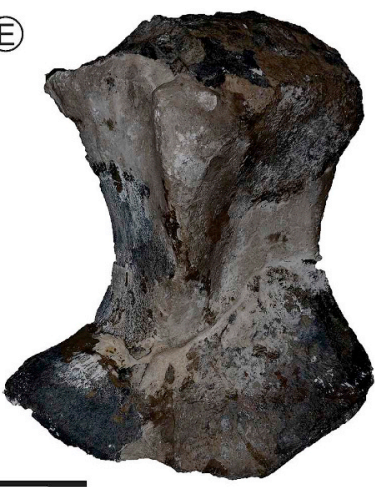

(B)
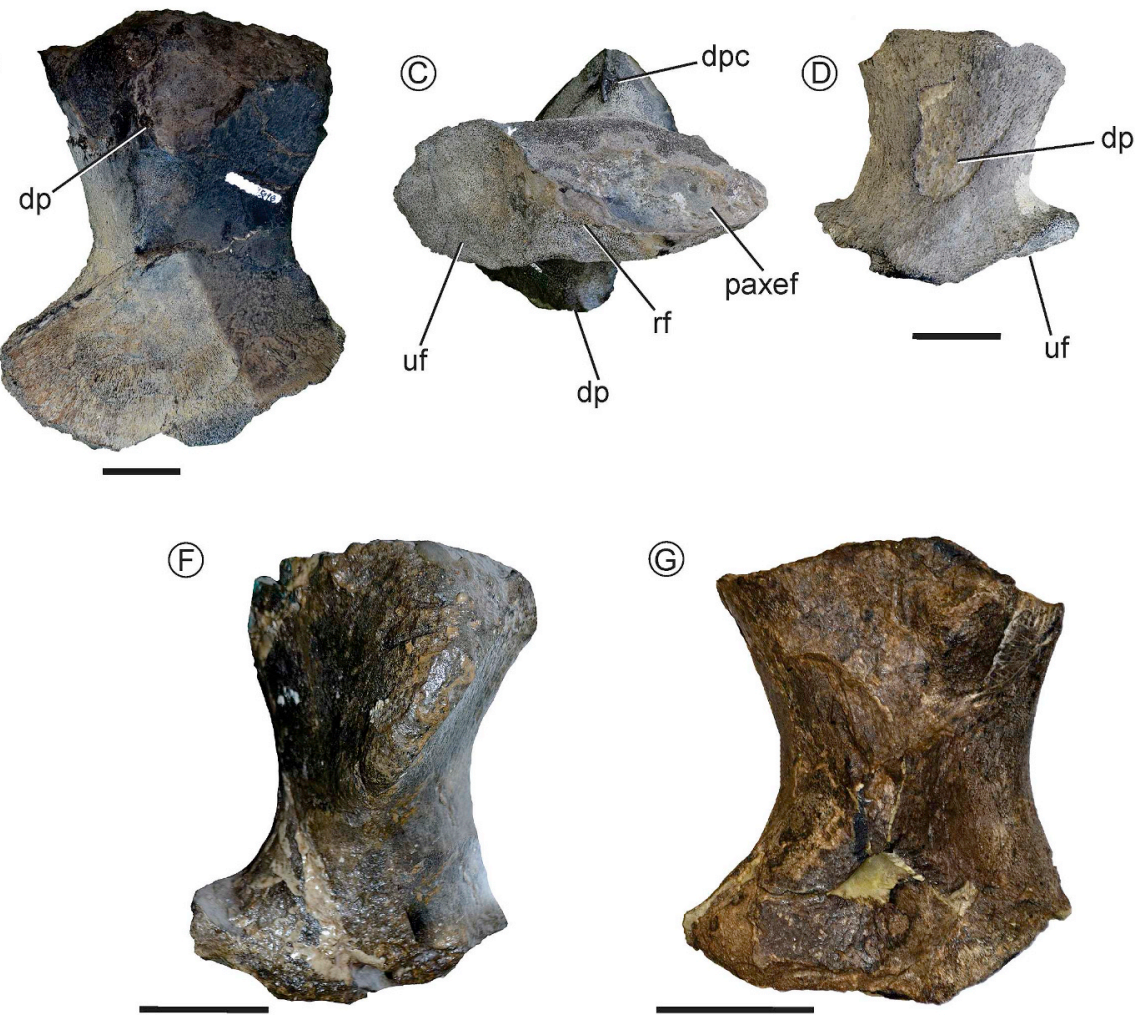

(G)

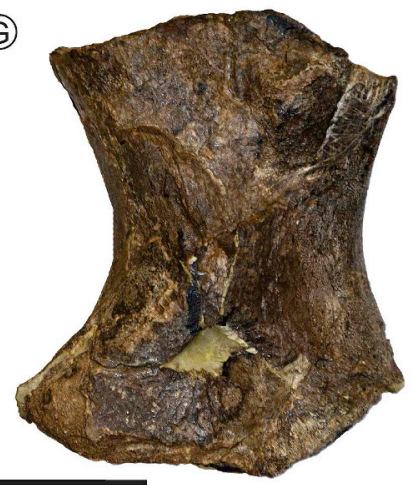

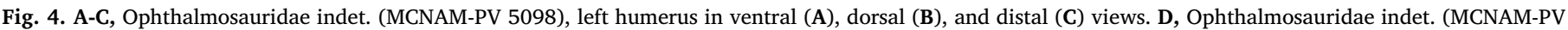

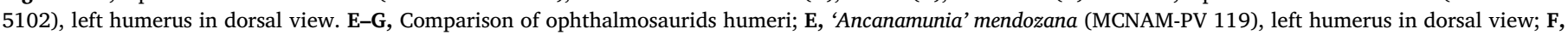

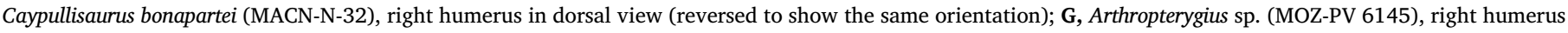
in dorsal view (reversed to show the same orientation). Scale bars $=3 \mathrm{~cm}(A-C), 2 \mathrm{~cm}$ (D), $5 \mathrm{~cm}$ (E-G). 
Material. MCNAM-PV 5102. Fragment of the left humerus and other undetermined bones included in a calcareous nodule.

Description. Small humerus, $53 \mathrm{~mm}$ of maximum length, with almost flat proximal end. Both conditions suggest an early ontogenetic state (Johnson, 1977). Most of the humerus is still included in the matrix but its dorsal surface is well exposed. The humerus is strongly dorsoventrally compressed and lacks its distal most part. Despite the difference in size, the relative anteroposterior expansion of the proximal and distal ends is similar to those of MCNAM-PV 5098 being the distal end slightly larger than the proximal one (proximal/distal width $=0.78$ and 0.88 respectively). The dorsal trochanter is broken but its outline has been preserved clearly marked on this surface, surpassing the middle of the humeral shaft. The constriction of the shaft is distally displaced, in comparison with that of MCNAM-PV 5097 and 5098, and the facet for the articulation with the preradial element and the ulna are clearly offset.

Remarks. The plate-like dorsal trochanter on the humerus allows the identification of this specimen as an Ophthalmosauridae sensu Motani, 1999. The general morphology of this specimen does not differ significantly from the other two specimens found in the same locality (MCNAM-PV 5097 and 5098) except for the distal extension of the dorsal trochanter and the relative offset of the distal articular facets. Immature ophthalmosaurids are poorly documented except for the fetal remains of Platypterygius australis (Kear and Zammit, 2014). Noteworthy, most of the features used in the systematics of this species are ontogenetically stable except for certain proportions including the relative development of the dorsal trochanter and distal articular facets. In this context, the differences between MCNAM-PV 5102 and the two larger specimens described above (MCNAM-PV 5097 and 5098) can be interpreted as ontogenetic. On this basis, the possibility that this specimen could represent a juvenile stage of the same taxon compatible with 'Ancanamunia' mendozana should not be rejected a priori.

\subsubsection{Crocodylomorphs}

Crocodylomorpha Hay, 1930 (sensu Walker, 1970)

Thalattosuchia Fraas, 1901 (sensu Young and Andrade, 2009)

Metriorhynchidae Fitzinger, 1843 (sensu Young and Andrade, 2009)

Metriorhynchinae Fitzinger, 1843 (sensu Young and Andrade, 2009)

Rhacheosaurini Young et al., 2011

Cricosaurus sp.

Fig. 5A-G; Table 1

Material. MCNAM-PV 5099. Incompletely preserved skull, teeth, cervical vertebrae, and coracoid recovered from a naturally cracked calcareous nodule.

Description. The external surface of the cranium is weathered. The maxilla with some fragmentary teeth on its posterior region is poorly preserved. In dorsal view the nasals are subtriangular in shape; however, the anterior most region is not preserved. The two posteromedial processes contact the frontal medially and the prefrontals laterally. As in other metriorhynchids, there is a longitudinal depression along the nasal-nasal suture (e.g. Young et al., 2013a) (Fig. 5A). The nasal forms the dorsal region of the preorbital fossa and most of the preorbital opening, as in Cricosaurus araucanensis (Fernández and Herrera, 2009). The right prefrontal is almost completely preserved. As in all metriorhynchids, the prefrontals are enlarged and expanded mediolaterally (being about twice longer than broad). In dorsal view, the prefrontals contact the nasals anteromedially and the frontal posteromedially. The frontal is incompletely and poorly preserved. As in C. lithographicus (MOZ-PV 5787) its anterior process extends anteriorly between the posteromedial processes of the nasal and does not reach the anterior margin of the prefrontal (Fig. 5A). An isolated fragment of the occipital surface preserves the U-shaped structure of the parietal (Fig. 5B). This feature is frequent, but not exclusive, in Cricosaurus spp. (Herrera et al., 2018). Infillings of the nasal cavity, nasal salt gland duct, and antorbital sinus are also preserved. Teeth are small, acute, bicarinated, and with some apicobasally aligned ridges of low relief, as in some Cricosaurus species. These ridges are developed at the base of the crown and vanish toward the apex (Fig. 5C-D), as in MCNAM-PV 5095. The atlas-axis complex is partially embedded in the sedimentary matrix and partially exposed in lateral view. The neural spine of the axis slopes up gradually from its anterior margin. The diapophysis is conspicuous and angled downwards. The axis is larger than the cervical vertebrae (Fig. 5E). Two post-axial cervical vertebrae are preserved; the centra are near $3 \mathrm{~cm}$ long. The diapophyses are associated with the neural arch whereas the parapophyses are on the centrum ventral to the diapophyses. The neurocentral suture is open (Fig. 5F). In both vertebrae the hypapophyses are well developed along the midline of the centrum, and the parapophyses are seen in ventral view. Thus, they may correspond to the first postaxial cervical vertebrae. The coracoid resembles that of $C$. araucanensis (Herrera et al., 2013a) being dorsoventrally flattened with expanded proximal and distal ends (Fig. 5G).

Remarks. Based on the U-shaped structure of the parietal and the tooth morphology (small, acute, bicarinated, with apicobasally aligned ridges of low relief) this specimen is referred to Cricosaurus.

Geosaurinae Lydekker, 1889 (sensu Young and Andrade, 2009)

Geosaurini Lydekker, 1889 (sensu Cau and Fanti, 2011)

Geosaurini indet.

Fig. 5H-K; Table 1

Material. MCNAM-PV 5100. Partially preserved dorsal vertebrae and right humerus.

Description. The dorsal vertebrae are hourglass shaped in ventral view, typical of metriorhynchids (e.g. Herrera et al., 2013a; Wilkinson et al., 2008; Young et al., 2013b). The centrum is approximately $7 \mathrm{~cm}$ long (Fig. 5H-I), a centra length that closely resembles those of Dakosaurus maximus (see Fraas, 1902). The prezygapophyses are separated by a deep and wide notch. The left transverse process is anteroposteriorly expanded at the base with the parapophysis forming a step-like prominence on the anterior margin of the transverse process. The neural spine is almost as high as the vertebral body. The proximal half of the right humerus is preserved. It is dorsoventrally compressed being convex in dorsal view (Fig. 5J), and concave in ventral view (Fig. 5K). The shaft is flattened, proximally expanded. The proximal articular surface has two rounded surfaces that form a continuous structure which continues in turn to the deltopectoral crest; however, there is a clear differentiation between them. The deltopectoral crest is well developed, projecting out from the humerus shaft (Fig. 5J-K).

Remarks. This specimen is assigned to the Geosaurini based on the morphology of the humerus and size of the vertebrae. The humerus of MCNAM-PV 5100 strongly resembles that of Dakosaurus maximus (SMNS 8203) and Torvoneustes carpenteri (Wilkinson et al., 2008) in the relative development of the deltopectoral crest and the relative expansion of its proximal end. The size of the vertebrae also resembles that of Dakosaurus maximus (SMNS 8203; Fraas, 1902) and MCNAM-PV 5094 (see below).

\section{Metriorhynchidae Fitzinger, 1843 \\ Metriorhynchidae indet. \\ Fig. 5L-M; Table 2}

Material. MCNAM-PV 5101. Natural cast of the preorbital region including salt glands, part of the nasal cavity, nasopharyngeal ducts, and antorbital sinus.

Description. The preorbital region has the same pattern previously reported for other metriorhynchids: external surface of salt gland composed of many small and rounded lobules, exocrine nasal gland duct running through the preorbital opening, and internalization of the antorbital cavity with the antorbital sinus housed within the maxilla 

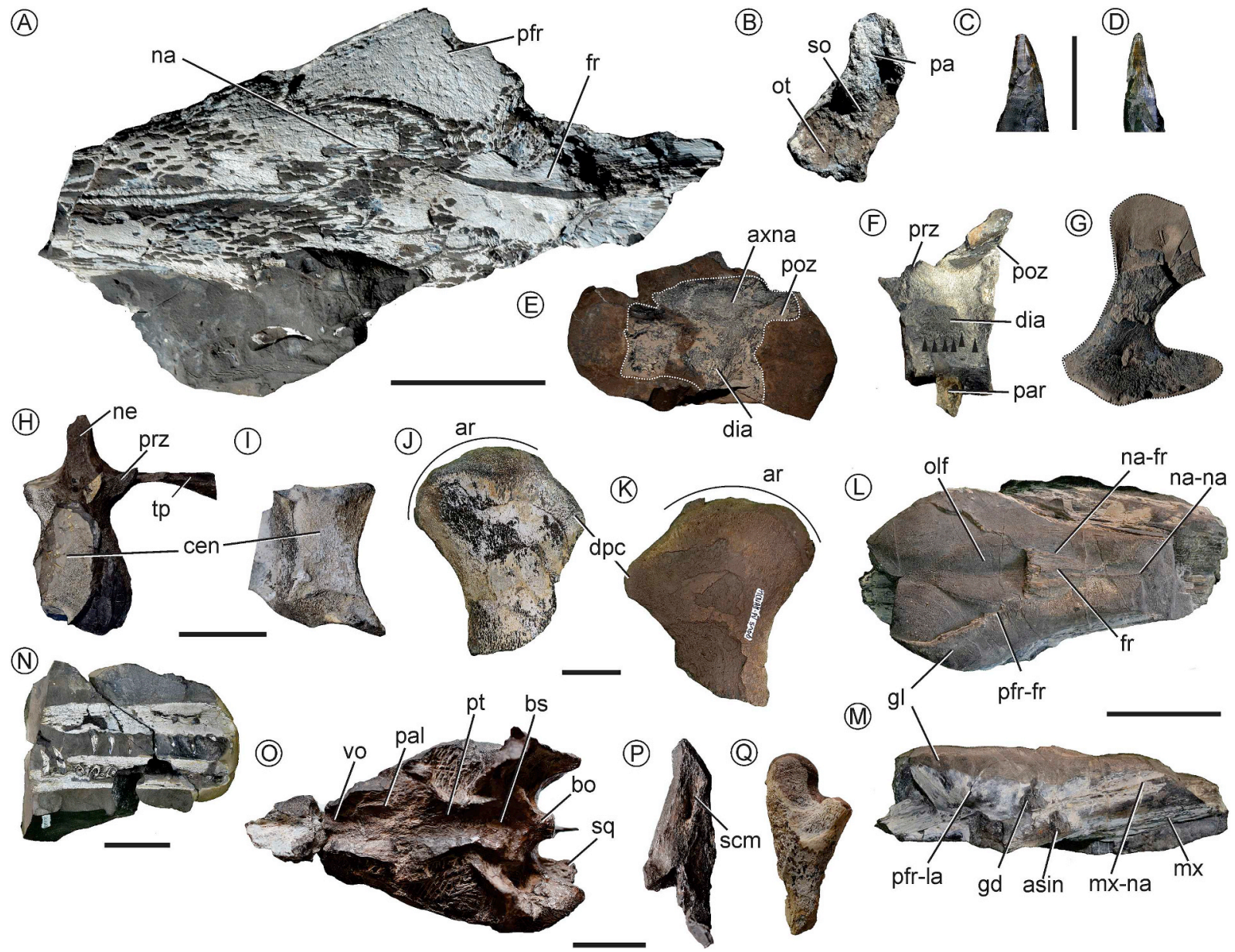

dia
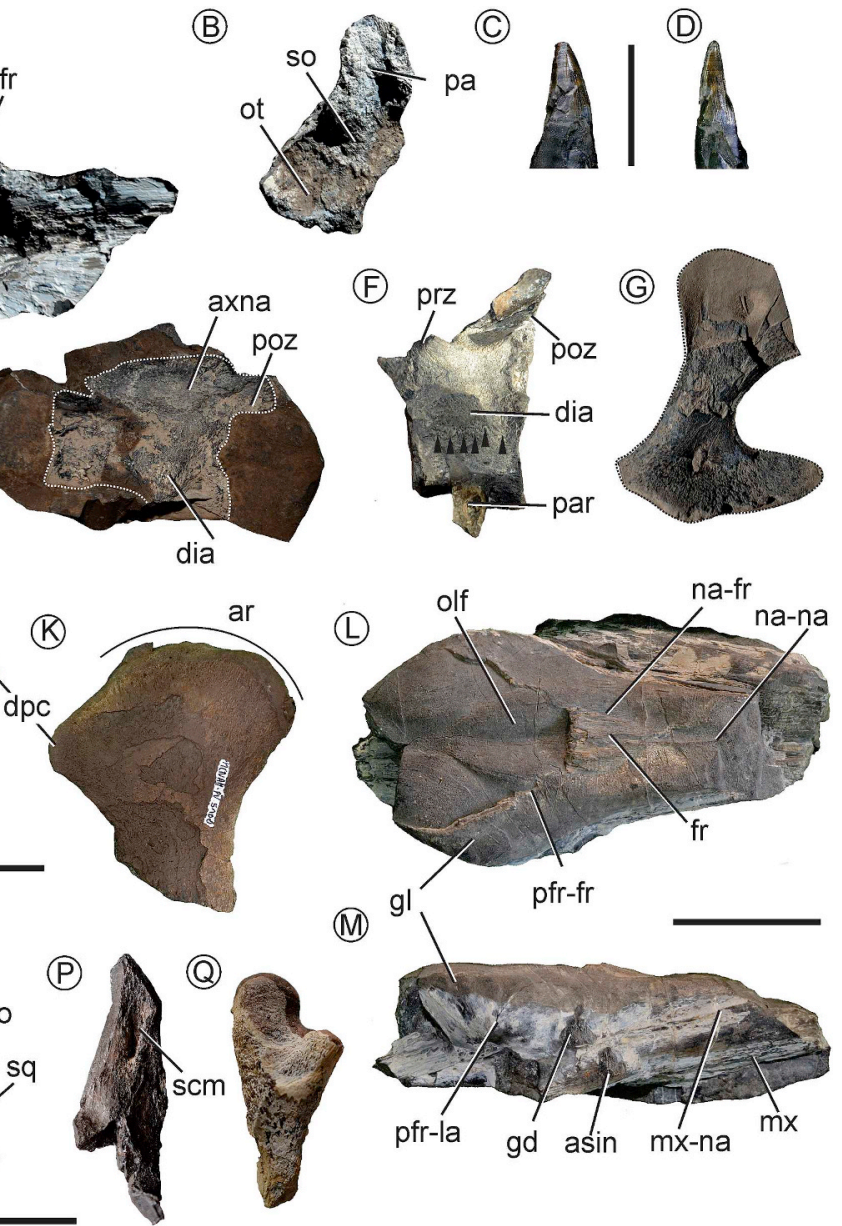

(M)

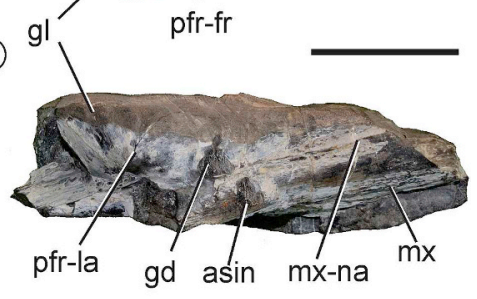

Fig. 5. Marine reptiles from Arroyo Durazno. A-G, Cricosaurus sp. (MCNAM-PV 5099); A, partially preserved cranium in dorsal view; B, partially preserved occipital surface in posterior view; C, tooth in labial view; D, tooth in posterior view; E, atlas-axis complex in left lateral view; $\mathbf{F}$, cervical vertebra in left lateral view; G, coracoid. H-K, Geosaurini indet. (MCNAM-PV 5100); H-I, dorsal vertebra in anterior (H) and ventral (I) views; J-K, right humerus in dorsal (J) and ventral (K) views. L-M, Metriorhynchidae indet. (MCNAM-PV 5101), natural cast in dorsal (L), and right lateral (M) views. N, Partially preserved snout of a Metriorhynchidae indet. (MCNAM-PV 5103) in lateral view. O-Q, Neusticemys neuquina (MHNSR-PV 1195); O, cranium in ventral view; P, lower jaw in medial view; Q, proximal portion of the left femur. Arrowheads in F indicate the neurocentral suture. Scale bars $=5 \mathrm{~cm}(\mathrm{~A}-\mathrm{B}, \mathrm{E}-\mathrm{G}-\mathrm{I}, \mathrm{L}-\mathrm{N}), 1 \mathrm{~cm}(\mathrm{C}-\mathrm{D}), 3 \mathrm{~cm}(\mathrm{~J}-\mathrm{K}, \mathrm{O}-\mathrm{Q})$.

(Fernández and Herrera, 2009; Herrera et al., 2013b) (Fig. 5L-M). In addition, in dorsal view, and between both exocrine glands, the olfactory region of the nasal cavity is preserved as two rostrocaudally elongated convexities (Fig. 5L), as in Cricosaurus araucanensis (Herrera et al., 2013b). Some remains of bones are preserved, and the maxillanasal, nasal-nasal, nasal-frontal, prefrontal-frontal, and prefrontal-lacrimal sutures can be recognized on the weathered external surface of the specimen.

Metriorhynchidae indet.

Fig. 5N; Table 2

Material. MCNAM-PV 5103. Incompletely preserved and damaged snout and mandible with teeth.

Description. The maxilla and dentary are exposed in lateral view. The external surface of bones is weathered. Several partially preserved teeth with thecodont implantation are preserved. Teeth are single cusped and acute.

\subsubsection{Turtles}

Testudinata Klein, 1760 (sensu Joyce et al., 2004)

Thalassochelydia Anquetin et al., 2017

Neusticemys Fernández and de la Fuente, 1993

Neusticemys neuquina (Fernández and de la Fuente, 1988)

\section{Fig. 5O-Q; Table 1}

Material. MHNSR-PV 1195, almost complete skull, cervical vertebrae, partial scapular and pelvic girdles, left and right humeri, left femur and tibia, plastral, costal and peripheral bones.

Description. The skull of MHNSR-PV 1195 is preserved in two portions: the main skull and a fragment of the peak formed by the premaxilla and remains of the maxilla and nasals in articulation with the main part of the skull. Its length (from the occipital condyle up to the tip the premaxilla) is $105 \mathrm{~mm}$. The skull is longer than wide, but with a relatively strong temporal emargination in comparison with other thalassochelydians. The general morphology and dermal ossification of the preserved roofing elements and the relatively strong temporal emargination are similar to those observed in the juvenile specimen (MACN-Pv-N 105) of N. neuquina. The dorsal surface of the skull is mostly weathered; remains of the nasal bones are recognized on the peak fragment, while remains of the frontal and most of the parietal bones are recognized in the main portion of the skull. On the lateral side of the skull, the quadratojugal roughly C-shaped resembles that of the juvenile specimen of N. neuquina (MACN-Pv-N 105). A well-developed parasagittal crest is developed on the dorsal surface of the squamosal. In ventral view, the most conspicuous features are, as in MACN-Pv-N 105 , the absence of secondary palate and the shape of the pterygoids which are wide at the level of the processus externus and narrow at the contact with the basisphenoid (Fig. 50). The left and right rami of the 
mandible are partially preserved (Fig. 5P). The proximal portion of the right humerus, partially preserved, narrows distally and bears, on its ventral surface, a relatively deep intertubercular fossa between the medial and lateral processes. The distal part of the shaft is slightly curved; it flattens dorsoventrally and expands into a broad distal end. The proximal portion preserves dorsally only the oval outline of the basis of the head, whereas the ectepicondylar sulcus and foramen are barely preserved in the distal ectepicondylar end. A remain of the pelvic girdle, likely represents right pubis and ischium. The left femur (Fig. 5Q) is preserved in two portions, missing only a minimal part of the shaft between both parts. Although femur and humerus are not complete, the femur seems to be slightly longer than the humerus. Its subrectangular head is set off from the dorsal shaft at an angle of approximately $130^{\circ}$. Only the trochanter minor is preserved. The sub cylindrical shaft arches dorsally, and expands distally bearing the tibial condyle partially covered by sediments. A remain of the stout tibia is still embedded in sediment and could not be described yet. Remains of costal bones are partially and poorly preserved, precluding further description. A left hypoplastron shows the characteristic morphology of $N$. neuquina (see Fernández and de la Fuente, 1988) with a wide central fenestra and a narrow medial interfingering contact with the right hypoplastron.

Remarks. The anatomic features of the skull (e.g. longer than wide with a relatively strong temporal emargination, well-developed parasagittal crest on the dorsal surface of the squamosal, absence of secondary palatal, pterygoids wide at the level of the processus externus and narrow at the contact with the basisphenoid), plastron (e.g. huge central fontanella and lateral ones, with hypoplastral medial interfingering contacts) and appendices (e.g. femur longer than humerus, humerus without a nearly straight shaft and a lateral process lying more distal to the caput humeri) fit with those of Neusticemys neuquina. This species is confirmed as a member of the thalassochelydian clade by the presence on the skull of a prominent infolding ridge on the posterior surface of the processus articularis of the quadrate (Anquetin et al., 2017).

The most up- to-date phylogeny performed by Evers and Benson (2019) defined the most inclusive Angolachelonia clade containing the Late Jurassic thalassochelydians and the Cretaceous-Paleogene sandownids. The thalassochelydian synapomorphy above mentioned by Anquetin et al. (2017) will be a synapomorphy of all taxa included in Angolachelonia. The following thalassochelydians synapomorphies (sensu Evers and Benson, 2019) recognized in N. neuquina are: presence of a fossa in the posterodorsal surface of the floor of the supraoccipital, the splenial is present in the lower jaw, the articulation of cervical vertebrae are not formed, and the costals lack lateral ossification, allowing the dorsal exposure of the distal end of ribs and the development of fontanelles at the most anterior and posterior costals.

\subsection{Arroyo Paulino}

\subsubsection{Ichthyosaurs}

Ophthalmosauridae

Platypterygiinae Arkhangelsky, 2001 (sensu Fischer et al., 2012)

Platypterygiinae indet.

Figs. 6, S4; Table 3

Material. MCNAM-PV 5089. A section of vertebral column, right pelvic girdle, and both hindfins included in a calcareous nodule approximately $2.80 \mathrm{~m}$ long. Only two caudal vertebrae were collected as voucher (Fig. 6D) but 28 posterior dorsal and/or anterior caudal centra were preserved or reconstructed on the basis of the imprint on the matrix.

Description. The skeleton is partially articulated with the articulated column section, one pelvic girdle and femur are approximately in their anatomical positions, and the hindfin elements (meso and autopodial elements) are scattered at both sides of the vertebral column (Fig. 6A). The relative position and articulation of the bones within the concretion are compatible with a ventral landing of the specimen on the sea floor (Delsett et al., 2016; Martill, 1993). According to this interpretation, the preserved pelvic girdle corresponds to the right one. The proportions of the vertebral centra could not be estimated except for two anterior caudals in which the height/length ratio is approximately 2.80 . The ilium is rod shaped, posteriorly curved. Its anterior edge is not regular and bears a slightly swollen area. Its length $(140 \mathrm{~mm})$ is approximately $84 \%$ of the ischiopubis length $(165 \mathrm{~mm})$, which is completely fused without any trace of foramen (Fig. 6C). The distal edge is 1.5 times more anteroposteriorly expanded than the proximal edge. Its anterior and distal edges are relatively straight, while the posterior one is concave. The right femur (Fig. 6B), $104 \mathrm{~mm}$ long, is preserved distally to the ischiopubis. The exposed surface of the femur is eroded hampering the identification of the main processes, and therefore, making difficult its orientation. Based on a putative ventral landing of the skeleton on the sea floor, and also on its orientation relative to the vertebral column, the exposed surface is interpreted as the dorsal one. Distally, the femur is notably expanded, and bears three distal articular facets being the fibular facet posterodorsally deflected. On the other side of the vertebral column, at the same level as the right femur, there is another bone equal in length, which is here interpreted as the other femur exposed on anterior or posterior view and depicting a strong trochanter.

Remarks. The specimen MCNAM-PV 5089 is referred to the Platypterygiinae sensu Fischer et al., 2012, based on the absence of a foramen in the ischiopubis and the presence of three distal articular facets on the femur. Although the identification of this specimen cannot be further explored at this stage, certain similarities of the pelvic girdle and femur, particularly with those of specimens from northern high latitudes are noteworthy. Similar to Keilhauia nui and Janusaurus lundi, the distal edge of the ischiopubis is almost straight in lateral view,

Table 3

In situ specimens from Arroyo Paulino.

\begin{tabular}{|c|c|c|c|c|}
\hline Collection or field number & Andean ammonite Zone & Taxon & Preserved elements & Figure reference \\
\hline MCNAM-PV 5096 & Argentiniceras noduliferum & Metriorhynchidae indet. & Partially preserved skull, tooth & Fig. 7F-G \\
\hline MCNAM-PV 5089 & Substeueroceras koeneni & Platypterygiinae indet. & Vertebrae (28), right pelvic girdle and fragments of both hind fins & Fig. 6 and S4 \\
\hline MCNAM-PV 5095 & Substeueroceras koeneni & Metriorhynchidae indet. & Skull and postcranial elements included in a large calcareous nodule & Fig. 8 \\
\hline MCNAM-PV 5093 & Corongoceras alternans & Cricosaurus sp. & Partially preserved cranium & Fig. 7C-E \\
\hline MCNAM-PV 5090 & Corongoceras alternans & Ichthyosauria indet. & $\begin{array}{l}\text { Partially preserved fin with a zeugopodial element articulated, vertebra } \\
\text { centra and ribs }\end{array}$ & Fig. S5 \\
\hline MCNAM-PV 5094 & Corongoceras alternans & Geosaurinae indet. & Partially preserved dorsal (12) and sacral vertebrae (2) & Fig. 7H-K \\
\hline Py METRIO 3 & Corongoceras alternans & Metriorhynchidae indet. & Skull exposed in dorsal view & Fig. S3A \\
\hline Py ICTIO 6 & Corongoceras alternans & Ichthyosauria indet. & Vertebra, ribs & Fig. S3D \\
\hline Py ICTIO 5 & Corongoceras alternans & Ichthyosauria indet. & Vertebrae (2) & Fig. S3C \\
\hline
\end{tabular}




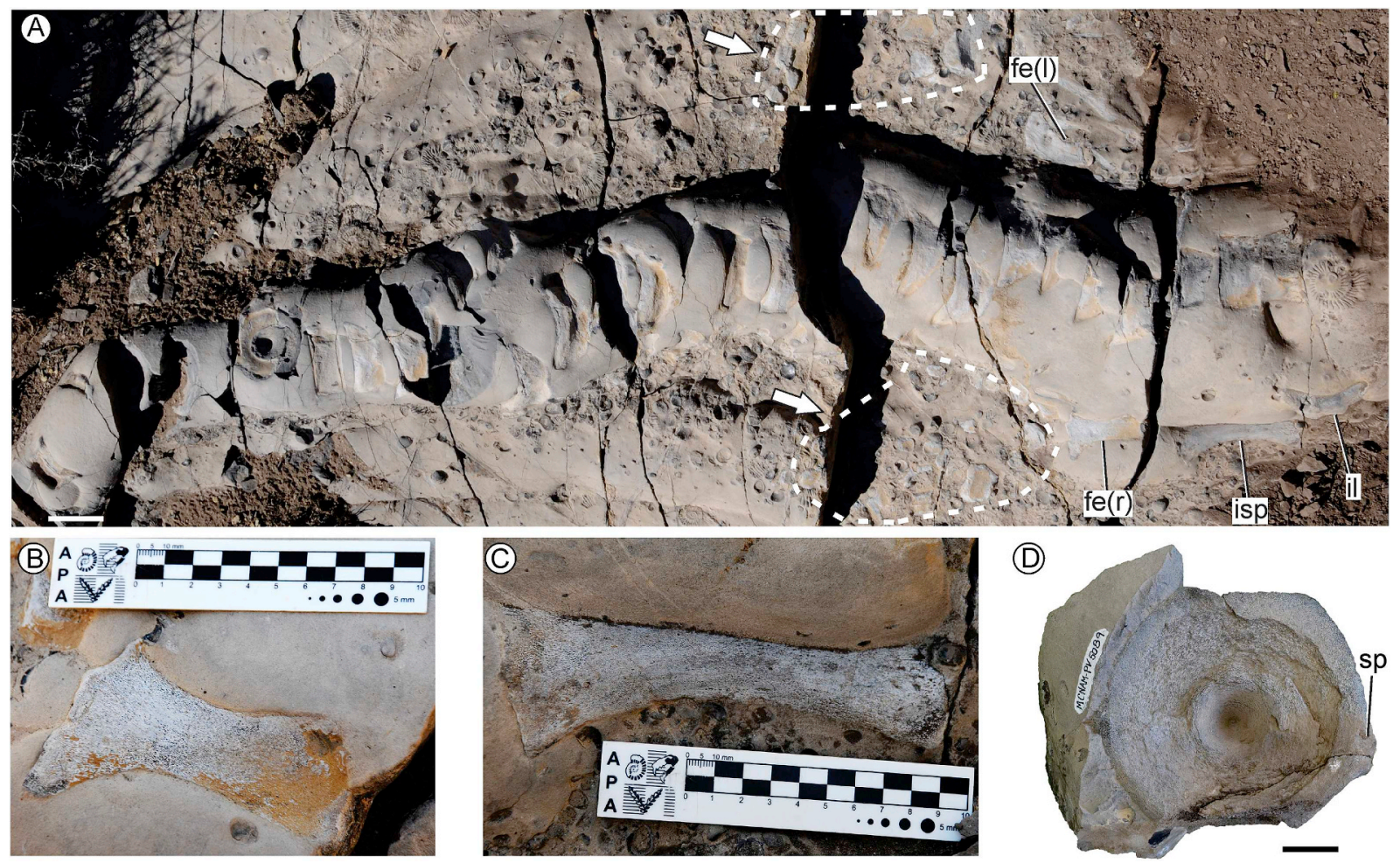

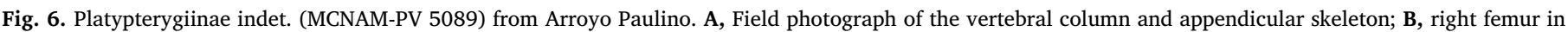

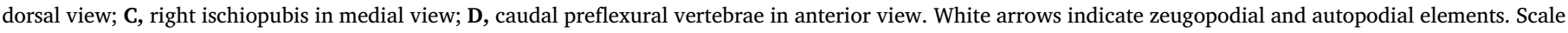
bars $=8 \mathrm{~cm}(\mathrm{~A}), 2 \mathrm{~cm}(\mathrm{D})$.

Table 4

Ex situ specimens from Arroyo Paulino.

\begin{tabular}{|c|c|c|c|}
\hline Collection or field number & Taxon & Preserved elements & Figure reference \\
\hline MCNAM-PV 5091 & cf. Dakosaurus & Partially preserved cranium & Fig. 7A-B \\
\hline Py ICTIO 3 & Ichthyosauria indet. & Vertebrae (2) & Fig. S3B \\
\hline
\end{tabular}

differing from those of most ophthalmosaurids (including Caypullisaurus) in which this edge is rounded. In addition, the ilium is proximodistally longer than the femur, as in Cryopterygius kristiansenae and Athabascasaurus bitumineus.

\section{Ichthyosauria indet.}

Fig. S5; Table 3

Material. MCNAM-PV 5090. Fragment of epipodial bone with an articulated zeugopodial element included in a calcareous nodule together with half of a vertebral centrum and ribs. Most of the nodule, including vertebra and ribs, has not been exhumed.

Description. The epipodial is $71 \mathrm{~mm}$ long and lacks dorsal and ventral processes due to erosion. Its proximal and distal edges are subequally anteroposteriorly expanded and the shaft bears a strong compression at the middle. Poor preservation prevents to determine with certainty if it is a humerus or a femur.

\subsubsection{Crocodylomorphs}

Geosaurinae Lydekker, 1889

Geosaurini Lydekker, 1889

cf. Dakosaurus

Fig. 7A-B; Table 4

Material. MCNAM-PV 5091. Partially preserved cranium, from the anterior end of the right nasal to half of the frontal. On the right side, the external surface is partially weathered exposing the exocrine nasal gland.

Description. The nasal is elongated, triangular in outline, and has a longitudinal depression along the nasal-nasal suture (Fig. 7A), as in most metriorhynchids (e.g. Herrera et al., 2013c; Young et al., 2013a). The nasal-frontal suture is posterolaterally directed forming a $50^{\circ}$ angle with the sagittal plane, similar to Dakosaurus andiniensis ( $\mathrm{Pol}$ and Gasparini, 2009). However, the posterodorsal process of the nasal appears to be longer than in D. andiniensis (MOZ-PV 6146) and D. maximus (SMNS 8203). The frontal has a wide anterior process that wedges between the two posterodorsal processes of the nasals (Fig. 7A), as in Dakosaurus spp. The external surface of the salt gland is composed of rounded lobules. The preorbital opening is marked on the external surface of the gland as a large almost circular structure. Infillings of the antorbital sinus can be recognized within the maxilla (Fig. 7B).

Remarks. The architecture of the cranium resembles that of Dakosaurus spp. Further preparation of the material may confirm whether it corresponds to $D$. andiniensis or not.

Metriorhynchinae Fitzinger, 1843

Rhacheosaurini Young et al., 2011

Cricosaurus sp.

Fig. 7C-E; Table 3

Material. MCNAM-PV 5093. Postorbital region of the cranium 
(A)

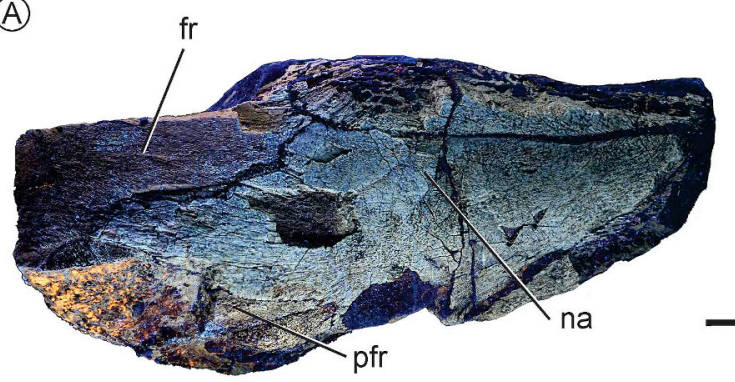

(B)

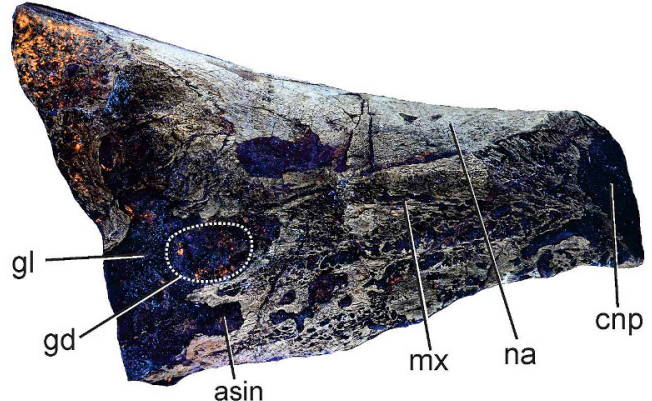

(C)

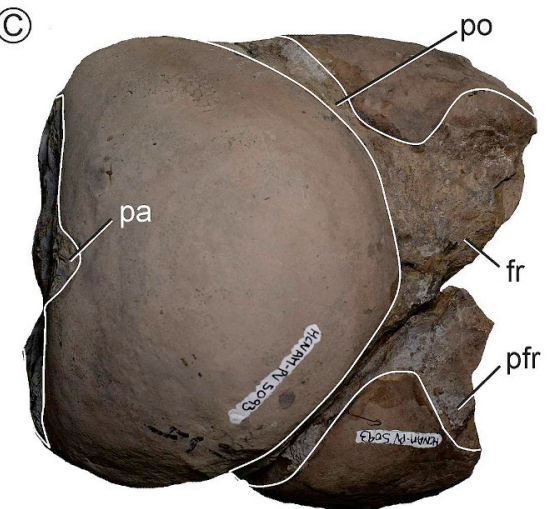

(F)

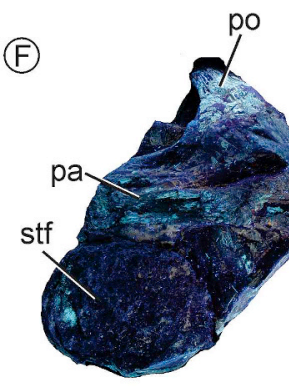

(1)

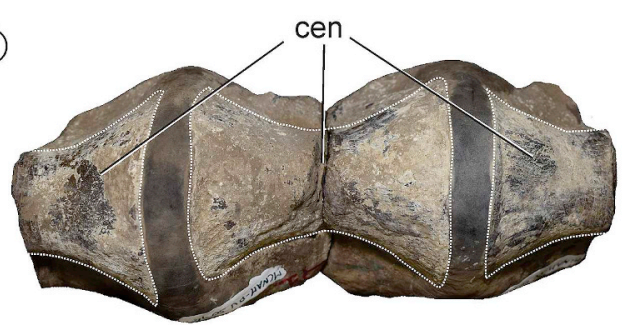

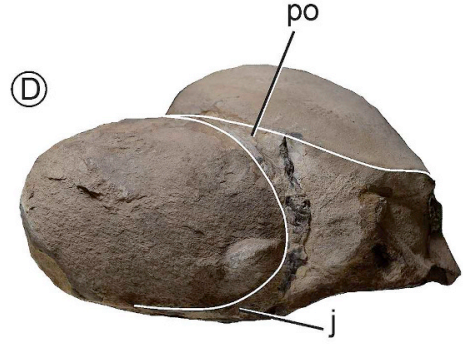

(D)
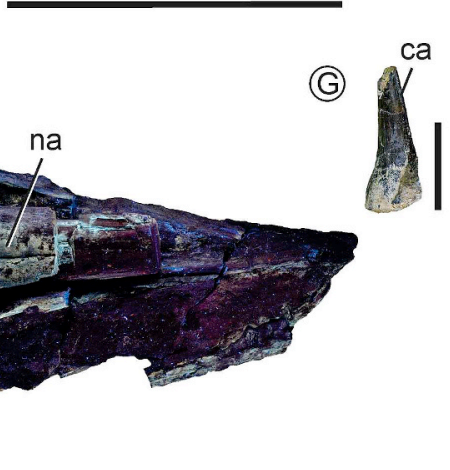

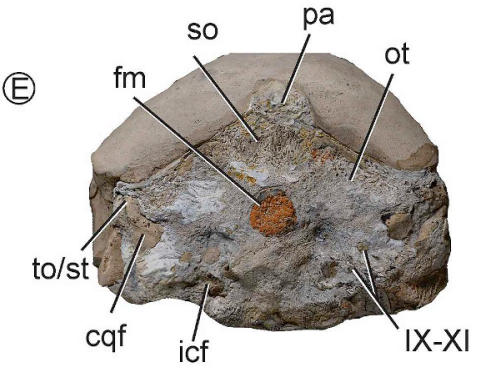

$(\mathbb{H})$

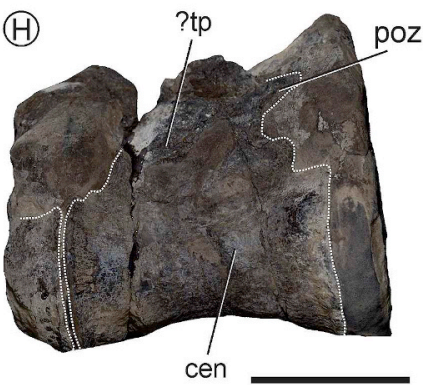

(J)
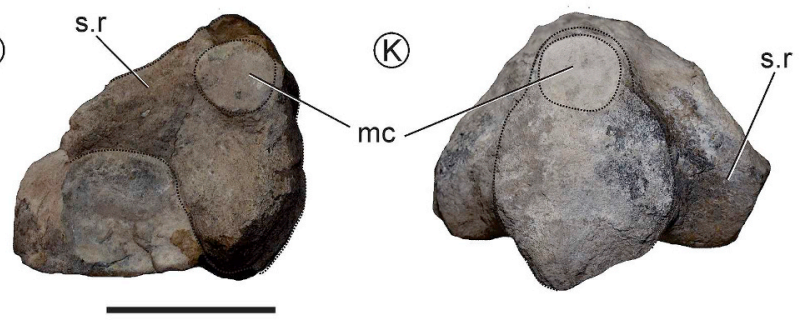

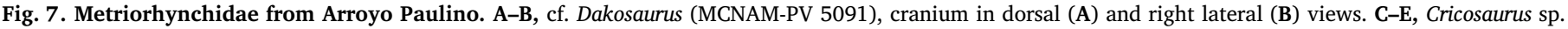

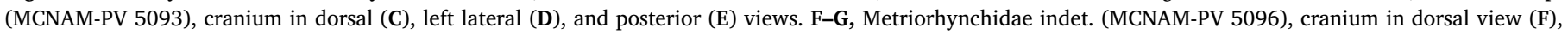

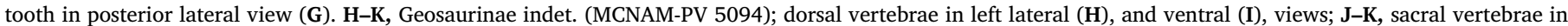
anterior/posterior views. Scale bars $=3 \mathrm{~cm}(\mathrm{~A}-\mathrm{B}), 10 \mathrm{~cm}(\mathrm{C}-\mathrm{E}), 5 \mathrm{~cm}(\mathrm{~F}, \mathrm{H}-\mathrm{K}), 1 \mathrm{~cm}(\mathrm{G})$.

included in a calcareous nodule. The dorsal, ventral and lateral regions of the cranium are partially exposed, whereas the occipital table is completely exposed.

Description. In dorsal view the postorbital processes of the frontal form an angle of $45^{\circ}$ with the sagittal plane of the skull (Fig. 7C), as in Cricosaurus spp. The infilling of the left orbital cavity is subcircular with the anteroposterior axis longer than the dorsoventral one (Fig. 7D). In occipital view, the parietal forms a semicircular or U-shaped structure, as in Cricosaurus araucanensis (MLP 72-IV-7-1), C. lithographicus (MOZPV 5787), and C. elegans (BSPG AS I 504). The parietal-squamosal bar is strongly projected ventrolaterally, as in C. araucanensis (Herrera and Vennari, 2015). The supraoccipital is exposed solely in occipital view. It is subrhomboidal, lateromedially longer than dorsoventrally. It contacts dorsally the parietal and ventrolaterally the otoccipital, and contributes to the dorsal margin of the foramen magnum. This latter is oval, with the major axis dorsoventrally oriented. The internal carotid artery foramen is enlarged, as is common in Thalattosuchia (Brusatte et al., 2016; Herrera et al., 2018). The distal portion of the temporo-orbital/ stapedial vein filling connects with the cranioquadrate foramen (Fig. 7E), as in other thalattosuchians (e.g. Fernández et al., 2011; Herrera and Vennari, 2015; Herrera et al., 2018; Pierce et al., 2017).

Remarks. The $45^{\circ}$ angle formed by the postorbital processes of the frontal, the parietal-squamosal bar projected ventrolaterally, and the Ushaped structure of the parietal, support the identification of the MCNAM-PV 5093 as Cricosaurus sp.

Metriorhynchidae indet.

Fig. 7F-G; Table 3 
Material. MCNAM-PV 5096. Incompletely preserved and diagenetically damaged skull. The anterior region of the snout and most of the braincase are not preserved.

Description. The nasals are large; although the anterior region is eroded exposing the cast of the nasal cavity. Along the midline, the dorsal surface of the nasals has a steep longitudinal depression, as in other thalattosuchians. The left prefrontal is preserved; although crushed and directed ventrolaterally, a well-developed lateral expansion overhangs the orbit, characteristic of metriorhynchids. The lateral margin is rounded, as in Cricosaurus spp. The interorbital region of the frontal is severely damaged. The angle formed by the lateral processes of the frontal and the midline of the skull is $\sim 40-50^{\circ}$, as in Cricosaurus spp. and Dakosaurus andiniensis. The dorsal surface of the intertemporal bar is eroded. The infilling of the right rounded supratemporal fenestra is preserved (Fig. 7F). In right lateral view, where the bone surface is missing, two subcircular structures are preserved, the dorsal one corresponds to the infilling of the nasal salt gland duct whereas the ventral one is the infilling of the antorbital sinus that is included within the maxilla. Two small $(\sim 1.5 \mathrm{~cm})$, single cusped and bicarinate teeth are preserved. The carinae appear to be slightly denticulate with the denticles unevenly distributed (Fig. 7G). However, SEM images are needed to confirm this. The ornamentation is composed of a few, widely distributed and discontinuous ridges.

Comment. The preparation of the specimen is still in progress; therefore its description may be extended in the future.

Geosaurinae Lydekker, 1889

Geosaurinae indet.

Fig. 7H-K; Table 3

Material. MCNAM-PV 5094. Incomplete articulated vertebral column composed by 12 dorsal and two sacral vertebrae partially preserved.

Description. As in all metriorhynchids, the vertebrae are hourglass shaped in ventral view (Fig. 7I). Most complete dorsal centra are $7-9 \mathrm{~cm}$ long. All vertebrae lack complete transverse processes, zygapophyses and/or neural spines (Fig. $7 \mathrm{H}-\mathrm{K}$ ). The centra in both anterior and posterior views are circular to elongate and the articular surface is slightly concave. In one of the dorsal vertebrae, the postzygapophysis extends slightly beyond the posterior margin of the centrum. Although incompletely preserved, the sacral ribs are ventrally deflected (Fig. 7J-K). The vertebral dimensions and shape resemble those observed in Dakosaurus maximus (SMNS 8203) and MCNAM-PV 5100.

Metriorhynchidae Fitzinger, 1843

Metriorhynchidae indet.

Fig. 8; Table 3

Material. MCNAM-PV 5095. The material was found in a large calcareous nodule in which the cranium and mandible were articulated (Fig. 8B), whereas the postcranial elements were completely disarticulated and mixed (Fig. 8A). The calcareous nodule was prepared in the field recovering the skull, vertebrae, ribs, and pectoral girdle elements. Only a few regions of the skull are exposed and can be described.

Description. The skull is about $50 \mathrm{~cm}$ long. The snout is partially exposed. Anteriorly, the preorbital fossa vanishes forming a groove excavated on the lateral surface of the maxilla, as in C. araucanensis (Fernández and Herrera, 2009). The single tooth preserved is small, acute and curved, with some apicobasally aligned ridges of low relief. The ridges begin at the base of the crown and vanish to the apex. At least one posterior carina was recognized.

Comment. The preparation of the specimen is still in progress; therefore its description may be extended in the future.

\section{Discussion}

The section at Arroyo Durazno encompasses the lower Tithonian to the lower-middle Berriasian while that of the Arroyo Paulino is restricted to the upper Tithonian to the lower Berriasian, and at both localities the marine succession is continuous. Recent analyses based on ammonites, calcareous nannofossils and calpionellids, and absolute U/ $\mathrm{Pb}$ ages, suggest that the Jurassic/Cretaceous boundary in the High Andes would lie within the top portion of the Substeueroceras koeneni Zone (Aguirre-Urreta et al., 2019; Lena et al., 2019; López-Martínez et al., 2017; Vennari et al., 2014). Our preliminary results suggest that the patterns of distribution of fossil marine reptiles of Mendoza are similar in both localities, and differ from other upper Tithonian and Tithonian-Berriasian localities of the central and southern Neuquén Embayment (Neuquén Province) previously published (Gasparini et al., 1997; Spalletti et al., 1999).

At both sections, marine reptiles have been recorded in beds assigned to all the Tithonian-lower Berriasian Andean ammonoid zones, while previous records elsewhere in the basin are restricted to middle to upper Tithonian-lower Berriasian. All the skeletons are preserved in, or associated with, carbonate nodules, which is frequent in Tithonian-Berriasian beds of the Vaca Muerta Formation cropping out in other localities of the Neuquén Embayment. At Arroyo Durazno and Arroyo Paulino, findings are common to abundant in beds assigned to the upper Tithonian Corongoceras alternans Zone (Microcanthum to "Durangites" Standard Zones), and are rare to common in beds assigned to the upper Tithonian-lower Berriasian Substeueroceras koeneni Zone ("Durangites" to Jacobi Standard Zones). While only a single specimen has been recovered from a lower Berriasian bed, assigned to the Argentiniceras noduliferum Zone (Occitanica Standard Zone). As shown on Fig. 2 and Tables 1 and 3, the beds assigned to Substeueroceras koeneni Zone are less fossiliferous than those assigned to the Corongoceras alternans Zone, being the marine reptile records abundant up to the base of the $S$. koeneni Zone. These differences could be explained in the context of facial change, related to a shallower environment upward in the stratigraphic column (Fig. 2) and not to an extinction event. On the contrary, at Trincajuera Creek and Yesera del Tromen/ Pampa Tril localities, marine reptiles have been collected from beds assigned to Substeueroceras koeneni Zone and none specifically from those assigned to the Corongoceras alternans Zone (e.g. Gasparini et al.,
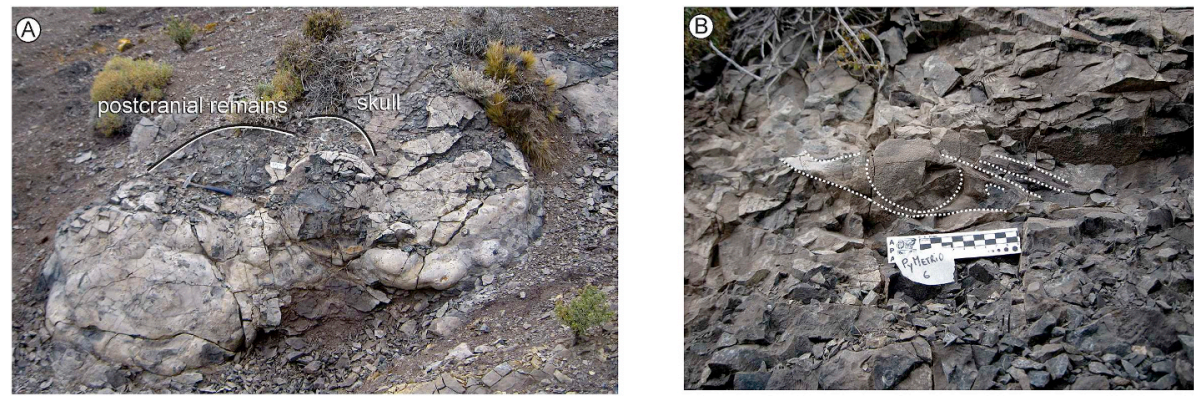

Fig. 8. Metriorhynchidae indet. (MCNAM-PV 5095). A, Calcareous nodules that contain the specimen; B, detailed of the nodule that contains the skull. 

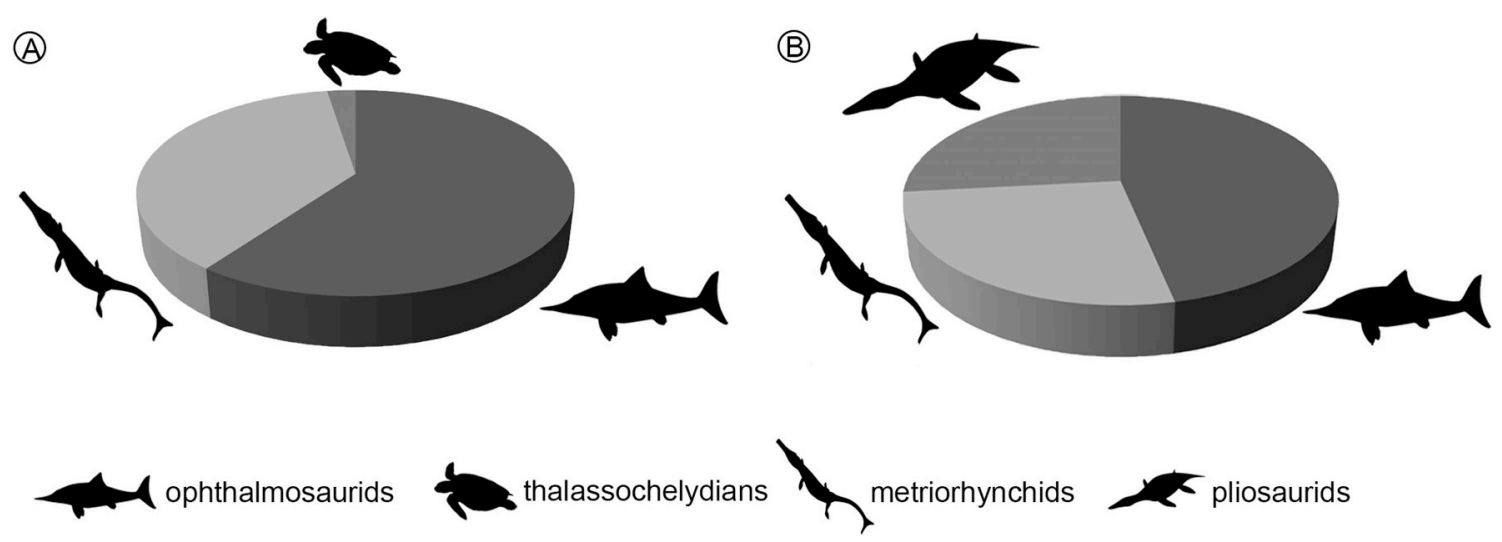

Fig. 9. Relative abundance of marine reptile findings at the High Andes, Mendoza Province (A) and Yesera del Tromen/Pampa Tril, Neuquén Province (B). Silhouettes taken from http://phylopic.org/.

1997; O'Gorman et al., 2018; Pol and Gasparini, 2009).

In comparison with Yesera del Tromen/Pampa Tril and Trincajuera Creek, the High Andes assemblages differ both in their faunal composition and their inferred feeding guild patterns of distribution. Both High Andes localities are dominated by ophthalmosaurid ichthyosaurs, approximately $60 \%$ of the total findings, no plesiosaurs have been found, and geosaurine and metriorhynchine metriorhynchids (plus one thalassochelydian turtle) complete the assemblages. At Yesera del Tromen/Pampa Tril, ichthyosaurs are the main component of the faunas (approximately half of the findings) but pliosaurs and metriorhynchids are equally abundant (Fig. 9; Spalletti et al., 1999). Total findings indicate that, at the High Andes, apex predators are represented by extreme hypercarnivorous geosaurines such as cf. Dakosaurus, and ichthyosaurs and metriorhynchines with tooth morphologies compatible with generalist and/or soft-prey predator specialists (Fischer et al., 2016; Massare, 1987) were the most abundant mesoconsumers. By contrast, in Yesera del Tromen/Pampa Tril and Trincajuera Creek assemblages geosaurine metriorhynchids and pliosaurs cooccurred as apex predators (or top predators, i.e. the predators at high trophic levels that fed on a wide range of prey including other vertebrates; Fischer et al., 2016). In addition, among apex predators found in Yesera del Tromen/Pampa Tril there is at least one gigantic pliosaur (M.S.F. pers.obs) that represents not only a predator that occupied higher trophic levels but also upon which no animal preyed on. Further comparisons are not possible due to the lack of quantitative data (including total findings) from the assemblage of Trincajuera Creek.

Regardless the putative sampling biases, and based on the Tithonian and Berriasian assemblages of the Vaca Muerta Formation throughout the Neuquén Basin, the general pattern of marine reptile communities depicts a relatively high ecological diversity of predators during the latest Jurassic. Considering total findings, Neusticemys neuquina is the most abundant of the two Jurassic species of turtles. Nineteen specimens of this Thalassochelydia turtle have been recovered from several localities of central and southern Neuquén Basin, whereas only four specimens from the panpleurodiran Notoemys laticentralis are known from Cerro Lotena and El Ministerio Quarry (de la Fuente and Fernández, 2011; Fernández and de la Fuente, 1993). Prey-preferences of extinct turtles in general and of Jurassic Thalassochelydia in particular, remain elusive, though the mandible morphology of Neusticemys is compatible with a soft-prey diet. Most of the ophthalmosaurid ichthyosaurs recovered from the Vaca Muerta Formation have not preserved the teeth (e.g. dentition is unknown in the most frequent ichthyosaur: Caypullisaurus bonapartei) indicating that teeth were not heavily anchored into the dental groove as it is expected in an apex predator. One specimen (MLP 85-I-15-1) identified by Fernández (1998) as C. bonapartei, is characterized by relatively long and slender teeth. However, the taxonomic referral of this specimen is doubtful and it is now under revision by one of the authors (L.C.). In the few specimens in which dentition is known as the platypterygiinae reported herein or the ophthalmosaurids from El Ministerio Quarry (Gasparini et al., 2015), tooth morphologies are compatible with a generalized and/or soft-prey diet. This inference is also valid for most of the metriorhynchids recovered from the Vaca Muerta Formation as Cricosaurus spp. Apex predators are commonly represented by geosaurine metriorhynchids at the High Andes assemblages, and by geosaurines and pliosaurids at central localities of the Neuquén Embayment (Gasparini et al., 1997; Spalletti et al., 1999). The use of negative evidence (i.e. the absence of certain taxa in faunal assemblages) is extremely risky; however, and based on our recent paleontological surveys as well as in published reviews and historical collections, it can be assumed that plesiosauroids were absent or were at least rare elements among the latest Jurassic marine reptile communities of the Neuquén Basin paleogulf.

Our survey documents several tens of novel occurrences of marine reptiles close to the Jurassic/Cretaceous boundary. This allows to compare the Vaca Muerta Formation assemblage to that of the Lagerstätte Slottsmøya Member (Agardhfjellet Formation, Svalbard, Norway) (e.g. Delsett et al., 2016; Hurum et al., 2012). Between 2004 and 2011, field trips carried out by the Spitsbergen Mesozoic Research group in the Arctic of the Svalbard archipelago resulted in outstanding discoveries and/or excavations of approximately 40 Tithonian-Berriasian marine reptiles (Hurum et al., 2011). Turtles and metriorhynchid crocodylomorphs are absent; the most abundant findings correspond to plesiosauroids and ophthalmosaurid ichthyosaurs, and apex predators are represented by pliosaurids (Hurum et al., 2012). The lack of metriorhynchids in the Slottsmøya Member Lagerstätte, so abundant in the assemblages from the Vaca Muerta Formation throughout the Neuquén Basin, could be due to the lower sea temperatures inferred for this high northern paleolatitude assemblage (Collignon and Hammer, 2012; Delsett et al., 2016; Hurum et al., 2012).

\section{Conclusions}

Fieldtrips carried out at the Tithonian-Berriasian exposures of the Vaca Muerta Formation cropping out at two localities of the High Andes (Arroyo Durazno and Arroyo Paulino) resulted in the discovery of rich and diverse marine reptile assemblages.

All reptile skeletons are preserved in, or associated with, calcareous nodules. The biostratigraphic ammonite-constrained distribution of the marine reptiles in both sections indicate that, although reptiles occurred in all the ammonoid zones, they are more frequent in beds assigned to the upper Tithonian Corongoceras alternans Zone (Microcanthum to "Durangites" Standard Zones), and are rare to common in beds assigned to the upper Tithonian-lower Berriasian 
Substeueroceras koeneni Zone ("Durangites" to Jacobi Standard Zones). At the area of southern Mendoza of the Neuquén Basin, the decrease in reptile records close to the Jurassic/Cretaceous boundary (i.e. top portion of the $S$. koeneni Zone) is probably more related to a shallowing upward trend than to an extinction event.

Both High Andes assemblages are characterized by the lack of plesiosauroids and pliosaurids. Their ecological structures indicate that the mesoconsumers ophthalmosaurids and metriorhynchine were abundant to common, and the apex predators geosaurines and thalassochelydian turtles were rare components of these faunas.

\section{Conflicts of interest}

The authors declare no conflict of interests.

\section{Declarations of interest}

None.

\section{Acknowledgements}

We thank G. Campos (MCNAM), A. Kramarz and M. Ezcurra (MACN), O. Rauhut (BSPG), and R. Schoch (SMNS) for the access to specimens under their care, D. Benedito, S. Vázquez, I. Maniel, M. Jannello, F. López, D. Kietzmann, L. Acosta Burllaile, and J.I. Ison for field assistance, and to C. Deschamps for English grammar corrections. We are also grateful to V. Fischer and two anonymous reviewers, who helped to improve the manuscript. This work was partially supported by Agencia Nacional de Promoción Científica y Tecnológica (PICTs 2016-1039, 2016-1016, 2016-0618, 2014-2597, 2013-0095), Universidad Nacional de La Plata (Proyecto Incentivos N853) and Universidad Nacional de Río Negro (PI-UNRN 40-A-660). This is the contribution R-276 of the Instituto de Estudios Andinos Don Pablo Groeber (UBA-CONICET).

\section{Appendix A. Supplementary data}

Supplementary data to this article can be found online at https:// doi.org/10.1016/j.jsames.2019.03.013.

\section{References}

Aguirre-Urreta, B., Naipauer, M., Lescano, M., López-Martínez, R., Pujana, I., Vennari, V., De Lena, L.F., Concheyro, A., y Ramos, M., 2019;al.,. The Tithonian chrono-biostratigraphy of the Neuquén Basin and related Andean areas: a review and update. J. South Am. Earth Sci. 92, 350-367. https://doi.org/10.1016/j.jsames.2019.03.019.

Anquetin, J., Püntener, C., Joyce, W.G., 2017. A review of the fossil record of turtles of the clade Thalassochelydia. Bull. Peabody Museum Nat. Hist. 58, 317-369.

Arkhangelsky, M.S., 2001. On a new ichthyosaur of the genus Otschevia from the Volgian Stage of the Volga Region near Ulyanovsk. Paleontol. J. 35, 629-634.

Baur, G., 1887. Ueber den ursprung der Extremitäten der Ichthyopterygia. Jahresberichte und Mitteilungen des Oberrheinischen Geologischen Vereines 20, 17-20.

Benson, R.B., Druckenmiller, P.S., 2014. Faunal turnover of marine tetrapods during the Jurassic-Cretaceous transition. Biol. Rev. 89, 1-23.

Blainville, H. de, 1835. Système d'Herpétologie. Nouvelles Annales du Museum d'Histoire Naturelle 4, 37-295.

Bodenbender, G., 1892. Sobre el terreno Jurásico y Cretáceo en Los Andes Argentinos entre el Rio Diamante y el Rio Limay. Boletín de la Academia Nacional de Ciencias en Córdoba; República Argentina, vol. 13. pp. 1-5.

Bracaccini, O., 1970. Rasgos tectónicos de las acumulaciones mesozoicas en las provincias de Mendoza y Neuquén, República Argentina. Revista Asociación Geológica Argentina 25, 275-284.

Brusatte, S.L., Muir, A., Young, M.T., Walsh, S., Steel, L., Witmer, L.M., 2016. The braincase and neurosensory anatomy of an Early Jurassic marine crocodylomorph: implications for crocodilian sinus evolution and sensory transitions. Anatom. Rec. 299, 1511-1530.

Burmeister, H., Giebel, G., 1861. Die versteinnerungen von Juntas in Tala des Rio Copiapó. Abhandlungen der Naturforschenden Gesellschaft Halle, vol. 6. pp. 111-144.

Cau, A., Fanti, F., 2011. The oldest known metriorhynchid crocodylian from the Middle Jurassic of North-eastern Italy: Neptunidraco ammoniticus gen. et sp. nov. Gondwana Res. 19, 550-565.
Collignon, M., Hammer, O., 2012. Petrography and sedimentology of the Slottsmoya Member at Janusfjellet, central Spitsbergen. Norweg. J. Geol. 92, 89-101.

Dames, W., 1893. Ueber das Vorkommen von Ichthyopterygiern im Tithon Argentiniens. Zeitschrift der Deutschen Geologischen Gesellschaft 45, 23-33.

de la Fuente, M.S., Fernández, M.S., 2011. An unusual pattern in the limb morphology of the Tithonian marine turtle Neusticemys neuquina from the Vaca Muerta Formation (Neuquén Basin) Argentina. Lethaia 44, 15-25.

de la Fuente, M.S., Vennari, V., Jannello, J.M., Maniel, I.J., González, P., Fernández, M.S, Aguirre Urreta, B., 2016. Una tortuga eucriptodira en el límite Titoniano-Berriasiano de la Cuenca Neuquina sur mendocina. Observaciones preliminares sobre la morfología y osteohistología. In: $11^{\circ}$ Congreso de la Asociación Paleontológica Argentina, Resúmenes, pp. 36-37.

Delsett, L.L., Novis, L.K., Roberts, A.J., Koevoets, M.J., Hammer, Ø., Druckenmiller, P.S, Hurum, J.H., 2016. The Slottsmøya Member marine reptile Lagerstätte: depositional environments, taphonomy and diagenesis. Geological Society Special Publications: Mesozoic Biotas of Scandinavia and its Arctic Territories, vol. 434. pp. 165-188.

Delsett, L.L., Roberts, A.J., Druckenmiller, P.S., Hurum, J.H., 2017. A new ophthalmosaurid (Ichthyosauria) from Svalbard, Norway, and evolution of the ichthyopterygian pelvic girdle. PLoS One 12, e0169971 https://doi.org/10.1371/journal.pone. 0169971.

Dessanti, R.N., 1978. Descripción geológica de la Hoja 28 b Malargüe (Provincia de Mendoza). Servicio Geológico Nacional, Boletín 149, 1-50.

Druckenmiller, P.S., Hurum, J.H., Knutsen, E.M., Nakrem, H.A., 2012. Two new ichthyosaurs (Ichthyosauria: Ophthalmosauridae) from the Agardhfjellet Formation (Upper Jurassic: Volgian), Svalbard, Norway. Norweg. J. Geol. 92, 311-339.

Evers, S.W., Benson, R.B.J., 2019. A new phylogenetic hypothesis of turtles with implications for the timing and number of evolutionary transitions to marine lifestyles in the group. Palaeontology 62, 93-134.

Fernández, M.S., 1998. Nuevo material de Caypullisaurus bonapartei Fernández (Reptilia: Ichthyosauridae) del Jurásico Superior de la Cuenca Neuquina, Argentina. Ameghiniana 35, 21-244.

Fernández, M.S., 1997. A new ichthyosaur from the Tithonian (Late Jurassic) of the Neuquen Basin, Northwestern Patagonia, Argentina. J. Paleontol 71, 479-484.

Fernández, M., 2003. Ophthalmosauria (Ichthyosauria) forefin from the AalenianBajocian boundary of Mendoza province, Argentina. J. Vertebr. Paleontol. 23, 691-694.

Fernández, M., 2007. Ichthyosauria. In: Gasparini, Z., Coria, R., Salgado, L. (Eds.), Patagonian Mesozoic Reptiles. Indiana University Press, Bloomington \& Indianapolis, pp. 271-291.

Fernández, M.S., de la Fuente, M.S., 1988. Una nueva tortuga (Cryptodira: Thalassemydidae) de la Formación Vaca Muerta (Jurásico: Titoniano) de la Provincia del Neuquén, Argentina. Ameghiniana 25, 129-138.

Fernández, M.S., de la Fuente, M.S., 1993. Las tortugas casiquelidias de las calizas litográficas titonianas del área Los Catutos Argentina. Ameghiniana 30, 283-295.

Fernández, M.S., Herrera, Y., 2009. Paranasal sinus system of Geosaurus araucanensis and the homology of the antorbital fenestra of metriorhynchids (Thalattosuchia: Crocodylomorpha). J. Vertebr. Paleontol. 29, 702-714.

Fernández, M.S., Maxwell, E.E., 2012. The genus Arthropterygius Maxwell (Ichthyosauria: Ophthalmosauridae) in the Late Jurassic of the Neuquén Basin, Argentina. Geobios 45, 535-540.

Fernández, M.S., Carabajal, A.P., Gasparini, Z., Chong Diaz, G., 2011. A metriorhynchid crocodyliform braincase from northern Chile. J. Vertebr. Paleontol. 31, 369-377. https://doi.org/10.1080/02724634.2011.550361.

Fischer, V., Maisch, M.W., Naish, D., Kosma, R., Liston, J., Joger, U., Krüger, F.J., Pardo Pérez, J., Tainsh, J., Appleby, R.M., 2012. New ophthalmosaurid ichthyosaurs from the European Lower Cretaceous demonstrate extensive ichthyosaur survival across the Jurassic-Cretaceous boundary. PLoS One 7, e29234. https://doi.org/10.1371/ journal.pone.0029234.

Fischer, V., Bardet, N., Guiomar, M., Godefroit, P., 2014. High diversity in Cretaceous ichthyosaurs from Europe prior to their extinction. PLoS One 9, e84709. https://doi org/10.1371/annotation/3b639689-59a3-4f4a-9ea0-11e9be043382.

Fischer, V., Bardet, N., Benson, R.B., Arkhangelsky, M.S., Friedman, M., 2016. Extinction of fish-shaped marine reptiles associated with reduced evolutionary rates and global environmental volatility. Nat. Commun. 7, 10825.

Fitzinger, L.J.F.J., 1843. Systema Reptilium, Fasciculus primus, Amblygossae: Wien, Braumüller et Seidel. pp. 1-106.

Fraas, E., 1901. Die Meerkrokodile (Thalattosuchia n.g.) eine Sauriergruppe der Juraformation. Jahreshefte der Gesellschaft für Naturkunde in Württemberg 57 $409-418$.

Fraas, E., 1902. Die Meer-Crocodilier (Thalattosuchia) des oberen Jura unter specieller Berücksichtigung von Dacosaurus und Geosaurus. Paleontographica 49, 1-72.

Gasparini, Z., 1973. Revisión de Purranisaurus potens Rusconi, 1948 (Crocodilia, Thalattosuchia). Los Thalattosuchia como un nuevo infraorden de los Crocodilia. Actas V Congreso Geológico Argentino 3, 423-431.

Gasparini, Z., 1985. Los reptiles marinos jurásicos de América del Sur. Ameghiniana 22, 23-34.

Gasparini, Z., Fernández, M., 2005. Jurassic Marine Reptiles in the Neuquén Basin. Geol. Soc. Lond. Spec. Publ. 252, 279-294.

Gasparini, Z., Fernández, M.S., 2011. Reptiles marinos mesozoicos. In: Leanza, H.A., Arregui, C., Carbone, O., Daniela, J.C., Vallés, J.M. (Eds.), Relatorio del XVIII Congreso Geológico Argentino. Asociación Geológica Argentina, Buenos Aires, pp. 529-538.

Gasparini, Z., Spalletti, L., de la Fuente, M., 1997. Marine reptiles of a tithonian transgression, western Neuquén Basin, Argentina. Facies and paleoenvironments. Geobios 30, 701-712.

Gasparini, Z., Fernández, M.S., de la Fuente, M., Herrera, Y., Codorniú, L., Garrido, A., 2015. Reptiles from lithographic limestones of the Los Catutos Member (MiddleUpper Tithonian), Neuquén Province, Argentina: an essay on its taxonomic 
composition and preservation in an environmental and geographic context. Ameghiniana 52, 1-28.

Goñi, R., 1987. Metriorhynchus aff. M. durobrivensis (Crocodylia, Thalattosuchia): un cocodrilo marino de la Formación Vaca Muerta, Mendoza, Argentina. Revista del Museo Argentino de Ciencias Naturales Bernardino Rivadavia 4, 1-8.

Groeber, P., 1946. Observaciones geológicas a lo largo del meridiano 70. 1. Hoja Chos Malal. Revista de la Sociedad Geológica Argentina 1, 177-208.

Hay, O.P., 1930. Second Bibliography and Catalogue of the Fossil Vertebrata of North America, vol. 2. Carnegie Institution of Washington, Washington, D.C., pp. 1-1074 390.

Herrera, Y., 2015. Metriorhynchidae (Crocodylomorpha: Thalattosuchia) from Upper Jurassic-Lower Cretaceous of Neuquén Basin (Argentina), with comments on the natural casts of the brain. Publicación Electrónica de la Asociación Paleontológica Argentina 15, 159-171.

Herrera, Y., Vennari, V.V., 2015. Cranial anatomy and neuroanatomical features of a new specimen of Geosaurini (Crocodylomorpha: Metriorhynchinae) from west-central Argentina. Hist. Biol. 27, 33-41. https://doi.org/10.1080/08912963.2013.861831.

Herrera, Y., Fernández, M.S., Gasparini, Z., 2013a. Postcranial skeleton of Cricosaurus araucanensis (Crocodyliformes: Thalattosuchia): morphology and palaeobiological insights. Alcheringa: Australas. J. Palaeontol. 37, 1-14. https://doi.org/10.1080/ 03115518.2013 .743709$.

Herrera, Y., Fernández, M.S., Gasparini, Z., 2013b. The snout of Cricosaurus araucanensis: a case study in novel anatomy of the nasal region of metriorhynchids. Lethaia 46, 331-340. https://doi.org/10.1111/let.12011.

Herrera, Y., Gasparini, Z., Fernández, M.S., 2013c. A new patagonian species of Cricosaurus (Crocodyliformes, Thalattosuchia): first evidence of Cricosaurus in Middle-Upper Tithonian lithographic limestones from Gondwana. Palaeontology 56, 663-678.

Herrera, Y., Gasparini, Z., Fernández, M.S., 2015. Purranisaurus potens Rusconi, an enigmatic metriorhynchid from the Late Jurassic-Early Cretaceous of the Neuquén Basin. J. Vertebr. Paleontol. 35, e904790. https://doi.org/10.1080/02724634.2014. 904790.

Herrera, Y., Leardi, J.M., Fernández, M.S., 2018. Braincase and endocranial anatomy of two thalattosuchian crocodylomorphs and their relevance in understanding their adaptations to the marine environment. PeerJ 6https://doi.org/10.7717/peerj.5686. e5686.

Huene, F. von, 1927. Beitrag zur Kenntnis mariner mesozoischer Wirbeltiere in Argentinien. Centralblatt für Mineralogie, Geologie und Paläontologie, B 1927. pp. $22-29$.

Hurum, J.H., Nakrem, H.A., Hammer Ø., Knutsen E.M., Hryniewicz, K., Rosseau, J., Høyberget, M., Druckenmiller, P., Little, C.T.S., 2011. The Upper Jurassic to Lower Cretaceous of Svalbard - a palaeontological bonanza. Wiman Meeting Uppsala, Abstracts 11.

Hurum, J.H., Nakrem, H.A., Hammer, Ø., Knutsen, E.M., Druckenmiller, P.S., Hryniewicz, K., Novis, L.K., 2012. An arctic Lagerstätte - the Slottsmøya Member of the Agardhfjellet Formation (Upper Jurassic-Lower Cretaceous) of Spitsbergen. Norwegian J. Geol. 92, 55-64.

Johnson, R., 1977. Size independent criteria for estimating relative age and the relationships among growth parameters in a group of fossil reptiles (Reptilia: Ichthyosauria). Can. J. Earth Sci. 14, 1916-1924.

Joyce, W.G., Parham, J.F., Gauthier, J.A., 2004. Developing a protocol for the conversion of rank-based taxon names to phylogenetically defined clade names, as exemplified by turtles. J. Paleontol. 78, 989-1013.

Kear, B.P., Zammit, M., 2014. In utero foetal remains of the Cretaceous ichthyosaurian Platypterygius: ontogenetic implications for character state efficacy. Geological Magazine 151, 71-86.

Kear, B.P., Lindgren, J., Hurum, J.H., Milan, J., Vajda, V., 2015. An introduction to the Mesozoic biotas of Scandinavia and its Arctic territories. Geol. Soc. Lond. Spec. Publ. 434, 1-14. http://doi.org/10.1144/SP434.2.

Klein, I.T., 1760. Klassification und kurze Geschichte der Vierfüßigen Thiere. Lübeck, pp. 1-381 (translation by F.D. Behn). Jonas Schmidt.

Knutsen, E.M., Druckenmiller, P.S., Hurum, J.H., 2012a. Two species of long-necked plesiosaurians (Reptilia-Sauropterygia) from the Upper Jurassic (Middle Volgian) Agardhfjellet Formation of central Spitsbergen, Norway. Norwegian J. Geol. 92, $187-212$.

Knutsen, E.M., Druckenmiller, P.S., Hurum, J.H., 2012b. A new plesiosauroid (ReptiliaSauropterygia) from the Agardhfjellet Formation (Middle Volgian) of central Spitsbergen, Norway. Norwegian J. Geol. 92, 213-234.

Knutsen, E.M., Druckenmiller, P.S., Hurum, J.H., 2012c. A new species of Pliosaurus (Sauropterygia: Plesiosauria) from the Middle Volgian, central Spitsbergen, Norway. Norwegian J. Geol. 92, 234-258.

Legarreta, L., Gulisano, C.A., 1989. Análisis estratigráfico de la cuenca Neuquina (Triásico Superior-Terciario Inferior). Cuencas Sedimentarias Argentinas, Serie Correlación Geológica 6, 221-244.

Legarreta, L., Uliana, M.A., 1991. Jurassic-Cretaceous marine oscillations and geometry of back-arc basin fill, central Argentine Andes. Int. Assoc. Sedimentol. Special Publ. 12, 429-450.

Legarreta, L., Uliana, M.A., 1999. El Jurásico y Cretácico de la Cordillera Principal y la Cuenca Neuquina. 1. Facies sedimentarias. In: Caminos, R. (Ed.), Geología Argentina. Instituto de Geología y Recursos Minerales, Buenos Aires, pp. 399-416.

Lena, L., López-Martínez, R., Lescano, M., Aguirre-Urrreta, B., Concheyro, A., Vennari, V., Naipauer, M., Samankassou, E., Pimentel, M., Ramos, V.A., Schaltegger, U., 2019. High-precision U-Pb ages in the early Tithonian to early Berriasian and implications for the numerical age of the Jurassic-Cretaceous boundary. Solid Earth 10, 1-14. https://doi.org/10.5194/se-10-1-2019.

López-Martínez, R., Aguirre-Urreta, B., Lescano, M., Concheyro, A., Vennari, V., Ramos, V.A., 2017. Tethyan calpionellids in the Neuquén Basin (Argentine Andes), their significance in defining the Jurassic/Cretaceous boundary and pathways for
Tethyan-Eastern Pacific connections. J. South Am. Earth Sci. 78, 116-125.

Lydekker, R., 1889. On the remains and affinities of five genera of Mesozoic reptiles. Q. J. Geol. Soc. 45, 41-59.

McGowan, C., Motani, R., 2003. Ichthyopterygia. Handbuch der Paläoherpetologie Part 8. Verlag Dr. Friedrich Pfeil, München, pp. 1-175.

Martill, D.M., 1993. Soupy substrates: a medium for the exceptional preservation of ichthyosaurs of the Posidonia Shale (Lower Jurassic) of Germany. Kaupia Darmstädter Beitr Natgesch 2, 77-97.

Massare, J.A., 1987. Tooth morphology and prey preference of Mesozoic marine reptiles. J. Vertebr. Paleontol. 7, 121-137.

Maxwell, E.E., 2010. Generic reassignment of an ichthyosaur from the Queen Elizabeth Islands, Northwest Territories, Canada. J. Vertebr. Paleontol. 30, 403-415.

McMullen, S.K., Holland, S.M., O'Keefe, R., 2014. The occurrence of vertebrate and invertebrate fossils in a sequence stratigraphic context: the Jurassic Sundance Formation, Bighorn Basin, Wyoming, U.S.A. Palaios 29, 277-294.

Meyer, C.E.H. von, 1830. Achte Versammlung der Naturforscher und Aerzte zu Heidelberg im September 1829. Mineralogische Abteilung 15, 517-519.

Motani, R., 1999. Phylogeny of the Ichthyopterygia. J. Vertebr. Paleontol. 19, 473-496.

Nullo, F.E., Stephens, G., Combina, A., Dimieri, L., Baldauf, P., Bouza, P., Zanettini, J.C.M., 2005. Hoja Geológica 3569-III/3572-IV, Malargüe, provincia de Mendoza. Servicio Geológico Minero Argentino. Instituto de Geología y Recursos Minerales. Boletín 346, 1-85.

O'Gorman, J.P., Gasparini, Z., Spalletti, L.A., 2018. A new Pliosaurus species (Sauropterygia, Plesiosauria) from the Upper Jurassic of Patagonia: new insights on the Tithonian morphological disparity of mandibular symphyseal morphology. J. Paleontol. 92, 240-243. https://doi.org/10.1017/jpa.2017.82.

Philippi, R., 1895. Ichthyosaurus immanis Ph. nueva especie Sud-Americana de este género. Anales de la Universidad de Chile 90, 837-841.

Pierce, S.E., Williams, M., Benson, R.B.J., 2017. Virtual reconstruction of the endocranial anatomy of the early Jurassic marine crocodylomorph Pelagosaurus typus (Thalattosuchia). PeerJ 5, e3225. https://doi.org/10.7717/peerj.3225.

Pol, D., Gasparini, Z., 2007. Crocodyliformes. In: Gasparini, Z., Coria, R., Salgado, L. (Eds.), Patagonian Mesozoic Reptiles. Indiana University Press, Bloomington \& Indianapolis, pp. 116-142.

Pol, D., Gasparini, Z., 2009. Skull anatomy of Dakosaurus andiniensis (Thalattosuchia: Crocodylomorpha) and the phylogenetic position of Thalattosuchia. J. Sys. Palaeontol. 7, 163-197. https://doi.org/10.1017/S1477201908002605.

Ramos, V.A., Folguera, A., 2005. Tectonic Evolution of the Andes of Neuquén: Constraints Derived from the Magmatic Arc and Foreland Deformation. Geol. Soc. Lond. Spec. Publ. 252, 15-35.

Roberts, A.J., Druckenmiller, P.S., Sætre, G.P., Hurum, J.H., 2014. A new Upper Jurassic ophthalmosaurid ichthyosaur from the Slottsmøya Member, Agardhfjellet Formation of central Spitsbergen. PLoS One 9, e103152.

Rusconi, C., 1938. Restos de ictiosaurios del Jurásico superior de Mendoza. Boletín Paleontológico de Buenos Aires 10, 1-4.

Rusconi, C., 1940. Nueva especie de ictiosaurio del Jurásico de Mendoza. Boletín Paleontológico de Buenos Aires 11, 1-4.

Rusconi, C., 1942. Nuevo género de ictiosaurio argentino. Boletín Paleontológico de Buenos Aires 13, 1-2.

Rusconi, C., 1948a. Ictiosaurios del Jurásico de Mendoza. Revista del Museo de Historia Natural de Mendoza 2, 17-160.

Rusconi, C., 1948b. Nuevo plesiosaurio, pez y langosta de mar jurásico de Mendoza. Revista del Museo de Historia Natural de Mendoza 2, 3-12.

Rusconi, C., 1967. Animales extinguidos de Mendoza y de la Argentina. Publicación Oficial del Gobierno de Mendoza 1-489.

Seeley, H.G., 1874. On the pectoral arch and forelimb of Ophthalmosaurus, a new ichthyosaurian genus from the Oxford Clay. Q. J. Geol. Soc. Lond. 30, 699-707.

Spalletti, L., Gasparini, Z., Veiga, G., Schwarz, E., Fernández, M., Matheos, S., 1999. Facies anóxicas, procesos deposicionales y herpetofauna de la rampa marina tithoniano berriasiana en la Cuenca neuquina (Yesera del Trómen), Neuquén, Argentina. Revista Geológica de Chile 26, 109-123.

Tennant, J.P., Mannion, P.D., Upchurch, P., 2016. Sea level regulated tetrapod diversity dynamics through the Jurassic/Cretaceous interval. Nat. Commun. 7, 12737.

Tennant, J.P., Mannion, P.D., Upchurch, P., Sutton, M.D., Price, G.D., 2017. Biotic and environmental dynamics through the Late Jurassic-Early Cretaceous transition: evidence for protracted faunal and ecological turnover. Biol. Rev. 92, 776-814.

Ugarte, F.R.E., 1955. Estudio geológico de la zona de Coihueco-Cerro de la Brea (Provincia de Mendoza). Rev. Asoc. Geol. Argent. 10, 137-178.

Vennari, V.V., Herrera, Y., Aguirre-Urreta, B., 2007. La Formación Vaca Muerta en el flanco Occidental de la Sierra Azul, Mendoza. Ameghiniana, Suplemento Resúmenes 44, 69R.

Vennari, V.V., Lescano, M., Naipauer, M., Aguirre-Urreta, B., Concheyro, A., Schaltegger, U., Armstrong, R., Pimentel, M., Ramos, V.A., 2014. New constraints on the Jurassic-Cretaceous boundary in the High Andes using high-precision U-Pb data. Gondwana Res. 26, 374-385.

Vignaud, P., Gasparini, Z., 1996. New Dakosaurus (Crocodylomorpha, Thalattosuchia) in the Upper Jurassic of Argentina. Comptes Rendus de l'Académie de Sciences 322, 245-250.

Walker, A.D., 1970. A revision of the Jurassic reptile Hallopus victor (Marsh), with remarks on the classification of crocodiles. Phil. Trans. Roy. Soc. Lond. B 257, 323-372.

Weaver, C., 1931. Paleontology of the Jurassic and Cretaceous of West Central Argentina. Memoirs of the University of Washington 1, pp. 1-496.

Wilkinson, L.E., Young, M.T., Benton, M.J., 2008. A new metriorhynchid crocodile (Mesoeucrocodylia: Thalattosuchia) from the Kimmeridgian (Upper Jurassic) of Wiltshire, UK. Palaeontology 51, 1307-1333.

Young, M.T., Andrade, M.B., 2009. What is Geosaurus? Redescription of Geosaurus giganteus (Thalattosuchia: Metriorhynchidae) from the Upper Jurassic of Bayern, Germany. Zool. J. Linnean Soc. 157, 551-585. 
Young, M.T., Bell, M.A., Brusatte, S.L., 2011. Craniofacial form and function in Metriorhynchidae (Crocodylomorpha: Thalattosuchia): modelling phenotypic evolution with maximum likelihood methods. Biol. Lett. 7, 913-916.

Young, M.T., Andrade, M.B., Etches, S., Beatty, B.L., 2013a. A new metriorhynchid crocodylomorph from the Lower Kimmeridge Clay Formation (Late Jurassic) of England, with implications for the evolution of dermatocranium ornamentation in Geosaurini. Zool. J. Linnean Soc. 169, 820-848.
Young, M.T., Andrade, M.B., Brusatte, S.L., Sakamoto, M., Liston, J., 2013b. The oldest known metriorhynchid super-predator: a new genus and species from the Middle Jurassic of England, with implications for serration and mandibular evolution in predacious clades. J. Sys. Palaeontol. 11, 475-513.

Zverkov, N.G., Fischer, V., Madzia, D., Benson, R.B.J., 2018. Increased pliosaurid dental disparity across the Jurassic-Cretaceous transition. Palaeontology 61, 825-846. https://doi.org/10.1111/pala.12367. 